\title{
New particle-dependent parameterizations of heterogeneous freezing processes: sensitivity studies of convective clouds with an air parcel model
}

\author{
K. Diehl and S. K. Mitra \\ Institute of Atmospheric Physics, Johannes Gutenberg University, Mainz, Germany \\ Correspondence to: K. Diehl (kdiehl@uni-mainz.de) \\ Received: 23 April 2015 - Published in Atmos. Chem. Phys. Discuss.: 17 June 2015 \\ Revised: 27 October 2015 - Accepted: 29 October 2015 - Published: 18 November 2015
}

\begin{abstract}
Based on the outcome of laboratory results, new particle-dependent parameterizations of heterogeneous freezing were derived and used to improve and extend a twodimensional spectral microphysics scheme. They include (1) a particle-type-dependent parameterization of immersion freezing using the numbers of active sites per mass, (2) a particle-type and size-resolved parameterization of contact freezing, and (3) a particle-type-dependent description of deposition freezing. The modified microphysical scheme was embedded in an adiabatic air parcel model with entrainment. Sensitivity studies were performed to simulate convective situations and to investigate the impact of ice nuclei concentrations and types on ice formation. As a central diagnostic parameter, the ice water fraction (IWF) was selected, which is the relation of the ice water content to the total amount of water in the condensed form. The following parameters were varied: initial aerosol particle number size distributions, types of ice nucleating particles, final temperature, and the fractions of potential ice nucleating particles. Single and coupled freezing processes were investigated. The results show that immersion freezing seems to be the most efficient process. Contact freezing is constrained by the collision kernel between supercooled drops and potential ice nucleating particles. The importance of deposition freezing lies in secondary ice formation; i.e., small ice particles produced by deposition nucleation trigger the freezing of supercooled drops by collisions. Thus, a broader ice particle spectrum is generated than that by immersion and contact freezing. During coupled immersion-contact and contact-deposition freezing no competition was observed, and both processes contribute to cloud ice formation but do not impede each other. As already suggested in the literature, mineral dust particles seem to be the
\end{abstract}

most important ice nucleating particles. Biological particles are probably not involved in significant ice formation. The sensitive parameters affecting cloud properties are temperature, aerosol particle composition and concentration, and particle size distribution.

\section{Introduction}

The importance of the ice phase in mixed-phase convective clouds is indisputable. The additional release of the latent heat of freezing enforces not only the strength of the convection, but also the presence of ice particles in the cloud substantially modifies the dynamical structure and the amount of precipitation (e.g., Gilmore et al., 2004). Hence, studying the ice phase in convective mixed-phase clouds is highly relevant for the understanding of such clouds and their atmospheric impact. With the convective updraft, water drops are transported into regions where the temperature is low enough to allow them to freeze. Homogeneous freezing (i.e., freezing that does not require the presence of ice nuclei) becomes efficient at temperatures below $-35^{\circ} \mathrm{C}$ (Pruppacher and Klett, 2010). Thus, at warmer temperatures in the troposphere heterogeneous freezing (which involves ice nucleating particles) is the only process of ice initiation, potentially triggering secondary ice formation. Heterogeneous freezing significantly changes the availability of liquid water in the upper parts of the clouds, since ice particles grow at the expense of liquid drops by the deposition of water vapor (Bergeron-Findeisen process) and by riming (i.e., collection of liquid water). Thus, the number of ice nucleating particles, as well as their efficiency to initiate ice formation at temperatures above the 
level of homogeneous freezing, determines the nature of convective clouds as it modifies cloud microphysical processes and cloud development (e.g., van den Heever et al., 2006; Ekman et al., 2007; Phillips et al., 2007; Lee et al., 2009).

For detailed investigations of cloud microphysical processes adiabatic parcel models with entrainment are often employed (e.g., Simmel et al., 2005; Leroy et al., 2006; Diehl et al., 2006; Diehl and Wurzler, 2010; Ervens and Feingold, 2012). Air parcel models describe a rising bubble of air, whose volume increases with height. The advantage of parcel models is that they allow for a detailed description of the cloud microphysical processes, usually achieved by the use of spectral-bin microphysical models that explicitly solve the microphysical equations (see Khain et al., 2000, for an overview).

The initiation of the ice phase in numerical models is always parameterized. As the ability of atmospheric particles to serve as ice nuclei varies over a wide temperature range for each freezing process (Pruppacher and Klett, 2010), parameterizations (for particular model simulations) are required that describe the effects of different types of ice nuclei. Model investigations that compared the effects of different ice nucleation schemes (Fan et al., 2010; Kulkarni et al., 2012; Ervens and Feingold, 2013) imply that cloud properties are sensitive to the surface properties of ice nucleating particles. In those studies particle surface properties were described by the contact angle $\mathrm{O}$. Other parameterizations were related directly to different particle types, and model studies showed that certain aerosol types significantly alter cloud microphysics (Diehl et al., 2006; Lohmann and Diehl, 2006; Phillips et al., 2008; Hoose et al., 2008; Storelvmo et al., 2008; Lee et al., 2009). They also allow one to simulate the effects of particular aerosols such as biomass burning particles (Diehl et al., 2007), biological particles (Phillips et al., 2009), bacteria (Diehl and Wurzler, 2010), or mineral dust (DeMott et al., 2015; Hande et al., 2015).

The present investigations are part of the German Science foundation (DFG) research group INUIT (Ice Nuclei Research UnIT), which was established to study heterogeneous ice formation in the atmosphere. In laboratory and field studies, the number concentrations, chemical composition, surface properties, and sources of atmospherically relevant ice nuclei are investigated in different freezing modes. As an outcome of these experiments, joint parameterizations are derived to be fed into a cloud model to simulate mixed-phase cloud microphysics and to quantify the contribution of ice nuclei particle types and freezing modes. For more details see the INUIT website: www.ice-nuclei.de.

One of the models employed during INUIT is an adiabatic air parcel model with entrainment and a detailed sectional description of the cloud microphysics. It describes immersion and contact freezing for various ice nuclei types such as mineral dust, soot, and biological particles (Diehl and Wurzler, 2004; Diehl et al., 2006). Until now deposition ice nucleation had not been included as it has been viewed as be- ing of less importance for ice formation in convective clouds. It might be negligible in mixed-phase clouds because water saturation is reached in the updraft after a short time (e.g., Ansmann et al., 2008, based on lidar observations). However, the formation of only a comparably small amount of ice (initiated by few very efficient ice nuclei) might result in secondary ice nucleation with highly complex interactions and consequences. The present version of the model was improved in a way that now it contains all heterogeneous freezing processes (deposition, contact, coupled condensation/immersion). This allows one to investigate the competition of the freezing modes to understand the importance of deposition freezing in comparison to immersion and contact freezing. The effects of various ice nucleating particles were compared to each other, considering the different freezing modes, to estimate their importance.

\section{Model description}

The impact of ice nucleating particles on mixed-phase convective clouds is investigated with a microphysical scheme embedded in an air parcel model with entrainment. The previous version of Diehl et al. (2006) was further developed in the way that new parameterizations were added or existing ones were modified or completely replaced.

The model of Diehl et al. (2006) contains a twodimensional spectral microphysics scheme, which divides the hydrometeor spectra into size bins (Simmel and Wurzler, 2006). These describe the number and mass of the drops or ice particles within the corresponding size range. A fixed bin structure is used, combining the wetted aerosol particles and the drops in one spectrum, where the soluble and total mass of aerosol particles is explicitly considered in every bin. An initial dry aerosol particle number size distribution is given where the particles are internally mixed with variable insoluble and soluble fractions. After starting the rise of the air parcel, the particles grow into the droplet part of the spectrum by condensation. The size spectra are allowed to evolve freely; they are not constrained by an underlying distribution function.

Here two-dimensional means that the microphysics is not a function of only the drop size (one-dimensional case) but a function of both drop and aerosol particle size (Simmel and Wurzler, 2006). In the one-dimensional case, equally sized drops contain only equally sized particles, which means that drops of the same size freeze at the same temperature (Diehl and Wurzler, 2004). However, in real clouds equally sized drops contain differently sized particles, which affect the freezing temperature of the drops. The soluble parts of the aerosol particles might lead to a freezing point depression (Koop et al., 2000; Diehl and Wurzler, 2004), while the insoluble fractions might give higher freezing temperatures via immersion freezing (see Sect. 2.1). Thus, the twodimensional description of microphysics allows for drops of 
the same size to freeze at different temperatures, which reflects drop freezing in atmospheric clouds in a more realistic way. It is divided into 90 categories for the particulate mass and into 66 categories for the water mass, both starting at $0.002 \mu \mathrm{m}$ in diameter, with a mass doubling in every category for the water mass and a mass doubling in every other category for the particulate mass. This combination is recommended in Simmel and Wurzler (2006).

The warm microphysical processes include growth of particles and drops by water vapor deposition, shrinking of particles and drops by evaporation, collision and coalescence, and impaction scavenging of particles. The entrainment of aerosol particles, drops, ice particles, temperature, and humidity is embedded (Simmel et al., 2005). The cold cloud microphysics describes immersion and contact freezing in parameterized form for various particle types (Diehl and Wurzler, 2004; Diehl et al., 2006). Condensation freezing is included implicitly in immersion freezing. Drops that are nucleated during the ascent of the air parcel by aerosol particles entrained above the freezing level could freeze immediately by immersion freezing. The growth of ice particles by water vapor diffusion and by riming (collision with supercooled droplets) is considered. Ice particles are sampled in a second spectrum, which shows the same bins as the aerosol particleliquid drop spectrum. Once drops are frozen or particles are involved in contact or deposition freezing (see next sections), they are shifted to the ice particle spectrum. The saturation ratio during growth and shrinking processes is iteratively calculated (Simmel and Wurzler, 2006).

Collision processes are described by the linear discrete method (Simmel et al., 2002) including the collision kernel of Kerkweg et al. (2003). By using the corresponding densities and terminal velocities, the collision kernel is appropriate for all collision processes between aerosol particles, drops, and ice particles, such as growth of drops by collision-coalescence, impaction scavenging of particles by drops, contact freezing of supercooled drops, growth of ice particles by riming, and secondary ice formation., i.e., freezing of supercooled drops by collision with an ice germ.

Because of the explicit descriptions mentioned above, the microphysical scheme is a useful tool to study the link between aerosol particles and the evolution of cloud properties in detail. The incorporation into an air parcel model has the advantage that all changes in the microphysical evolution of the cloud can be attributed to microphysical processes. The model improvements presented in the next sections include the following:

1. an updated particle-type-dependent description of immersion freezing, which is now related to the mass of insoluble particles contained in drops;

2. a modified description of contact freezing, which is dependent on not only particle type but also particle sizeresolved;
3. a new particle-type-dependent description of deposition freezing.

All parameterizations are directly based on previous and new laboratory measurements as described in the following sections.

\subsection{Immersion freezing}

The previous description of immersion freezing (Diehl and Wurzler, 2004) gave the freezing rate of pure water drops containing ice nucleating particles as a function of the drop volume according to

$-\frac{\mathrm{d} N_{\mathrm{f}}}{\mathrm{d} t}=N_{\mathrm{liq}} B_{\mathrm{imm}} V_{d} \exp \left(-a_{1, \mathrm{imm}} T\right) \frac{\mathrm{d} T}{\mathrm{~d} t}$,

where $N_{\mathrm{f}}$ is the number of frozen drops, $N_{\text {liq }}$ the number of liquid drops, and the constants $a_{1, \mathrm{imm}}$ and $B_{\mathrm{imm}}$. This parameterization implicitly reflected the fact that larger drops contain more particles because of collision and coalescence of drops and impaction scavenging of aerosol particles. The previous version was replaced by a new one, which is coupled directly to the mass of insoluble particles in the drops. This is possible because of the sectional distribution of drops and particles into size classes (Diehl et al., 2006).

\subsubsection{Parameterizations based on laboratory data}

The experimental data used as a basis for the parameterizations include the following ice nucleating particle types: bacteria, pollen, feldspar, illite, and kaolinite. Murray et al. (2011) investigated kaolinite KGa-1b and Atkinson et al. (2013) K-feldspar. Illite NX was studied by Broadley et al. (2012) and recently by Hiranuma et al. (2015). The latter publication summarized the results from 17 experimental techniques. Wex et al. (2015) include the results from seven experimental techniques using Snomax ${ }^{\circledR}$ as a proxy for bacteria; previous data for pollen (Diehl et al., 2002; v. Blohn et al., 2005) were newly evaluated. As a parameter for immersion freezing, the number of active sites per unit mass $n_{\mathrm{m}}$ was selected as this is derived directly from the particle mass concentration in the drops during the experiments. Some references give as an outcome from their measurements the surface density of active sites per unit particle surface $n_{\mathrm{s}}$; however, this parameter was derived afterwards by using a specific particle surface.

For kaolinite KGa-1b, K-feldspar, and tree and grass pollen, an exponential increase of $n_{\mathrm{m}}$ with temperature $T$ was found, which is described by

$n_{\mathrm{m}}=\exp \left(a_{\mathrm{imm}}+b_{\text {imm }} T_{\mathrm{s}}\right)$

where $n_{\mathrm{m}}$ is in $\mathrm{g}^{-1}, a_{\mathrm{imm}}$ and $b_{\mathrm{imm}}$ are particle-related constants, $T_{\mathrm{s}}=T_{0}-T$, and $T_{0}=0^{\circ} \mathrm{C}$, with $T$ in ${ }^{\circ} \mathrm{C}$. The constants for all particle types are listed in Table 1. Given in Table 1 are also the parameters $T_{\text {ini }}$ and $T_{\text {lim }}$, representing 


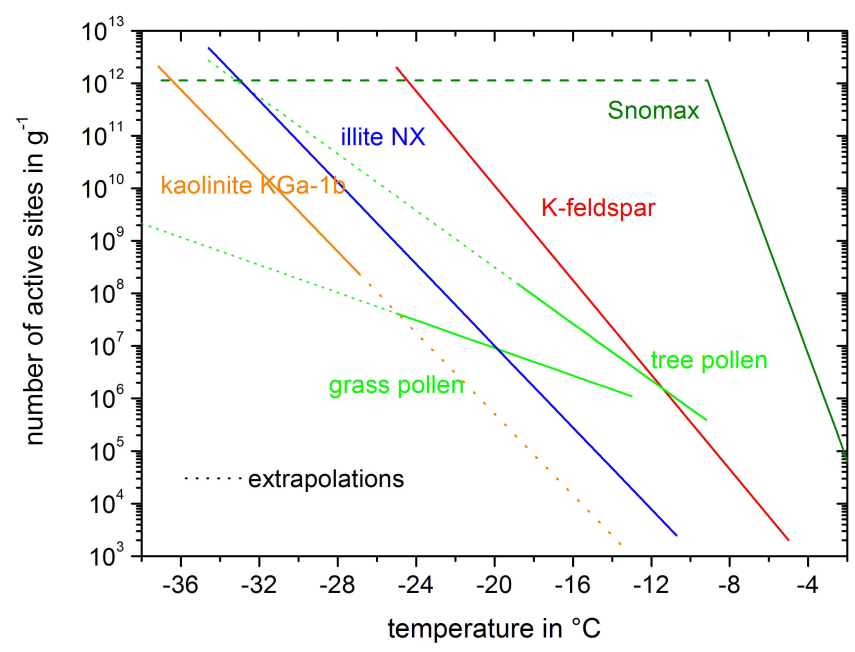

Figure 1. Numbers of active sites per unit mass as a function of temperature calculated by Eq. (2) with constants given in Table 1 for various particle types in the immersion mode. Based on laboratory data of immersion freezing experiments (Diehl et al., 2002; v. Blohn et al., 2005, pollen; Murray et al., 2011, kaolinite KGa-1b; Atkinson et al., 2013, K-feldspar; Hiranuma et al., 2015, illite NX; Wex et al., 2015, Snomax ${ }^{\circledR}$.

the onset of immersion freezing during experiments and the lowest temperature that was investigated in the experiments, respectively.

Based on the best fit of the data of Murray et al. (2011), the constants in Eq. (2) were derived for kaolinite KGa-1b by using an average specific particle surface area of $11.8 \mathrm{~m}^{2} \mathrm{~g}^{-1}$ as given by Murray et al. (2011); the result is shown in Fig. 1 as an orange line. The solid part of the line represents the range that is validated by measurements of Murray et al. (2011) while the dotted part shows an extrapolation towards higher temperatures. The value of $T_{\mathrm{ini}}$ is based on earlier measurements of Pitter and Pruppacher (1973). The same was performed for K-feldspar by using the best fit to the experimental data given by Atkinson et al. (2013), which were changed into Eq. (2) by using the specific particle surface area of $3.2 \mathrm{~m}^{2} \mathrm{~g}^{-1}$ from Atkinson et al. (2013). The parameters are listed in Table 1, the result of Eq. (2) is shown in Fig. 1 as a red line. Regarding pollen, previous data from Diehl et al. (2002) and v. Blohn et al. (2005) were evaluated. From the frozen fractions of drops, the drop volume, and the mass of pollen in the drops, the numbers of active sites $n_{\mathrm{m}}$ as functions of temperature were calculated according to (e.g., Murray et al., 2011)

$n_{\mathrm{m}}=-\frac{\ln \left(1-f_{\text {ice }}(T)\right)}{c_{\text {pollen }} V_{\text {drop }}}$,

where $f_{\text {ice }}(T)$ is the fraction of frozen drop at temperature $T, c_{\text {pollen }}$ the pollen concentration per drop, and $V_{\text {drop }}$ the drop volume. Data for tree and grass pollen were summarized leading to two parameterizations for tree and grass pollen as
Table 1. Values of immersion freezing constants in Eq. (2). Based on data from ${ }^{1}$ Wex et al. (2015), ${ }^{2}$ Diehl et al. (2002), ${ }^{3}$ v. Blohn et al. (2005), ${ }^{4}$ Atkinson et al. (2013), ${ }^{5}$ Hiranuma et al. (2015), and ${ }^{6}$ Murray et al. (2011).

\begin{tabular}{lrrrr}
\hline Particle type & $a_{\text {imm }}$ & $b_{\text {imm }}$ & $T_{\text {ini }}{ }^{\circ} \mathrm{C}$ & $T_{\text {lim }}{ }^{\circ} \mathrm{C}$ \\
\hline Bacteria $^{1}$ & 6.41344 & 2.33592 & -2 & -9.139 \\
Tree pollen $^{2,3}$ & 7.16249 & 0.62053 & -9 & -38 \\
Grass pollen $^{2,3}$ & 9.9731 & 0.030301 & -12 & -38 \\
Feldspar $^{4}$ & 2.10379 & 1.038 & -5 & -25 \\
Illite $^{5}$ & -1.77473 & 0.89507 & -10 & -37 \\
Kaolinite $^{6}$ & -4.61608 & 0.8881 & -13 & -37 \\
\hline
\end{tabular}

given in Eq. (2). The constants are listed in Table 1 and the results of Eq. (2) are shown in Fig. 1 as light green lines. The solid parts of the lines represent the ranges, which are validated by measurements, while the dotted parts show extrapolations towards lower temperatures.

Regarding illite NX and Snomax ${ }^{\circledR}$, parameterizations were suggested by Broadley et al. (2012), Hiranuma et al. (2015), and Wex et al. (2015). In order to derive analogue descriptions, as in the cases of the other particle types, these parameterizations were replaced by new ones following Eq. (2). Regarding illite NX, the parameterization was derived from the data reported by Hiranuma et al. (2015). The fit as given by Hiranuma et al. (2015) was changed into an expression for $n_{\mathrm{m}}$ by using the specific particle surface area of $124.4 \mathrm{~m}^{2} \mathrm{~g}^{-1}$ of the illite NX sample (Hiranuma et al., 2015). From the nonlinear curve (solid blue line in Fig. 2) a linear regression line was derived, which is included in Fig. 1 (blue solid line). For Snomax ${ }^{\circledR}$, it was concluded in Wex et al. (2015) that the average $n_{\mathrm{m}}$ values (given in Fig. 2 as open green symbols) are very well represented by the Hartmann et al. (2013) parameterization (solid green line in Fig. 2). One can notice a linear increase in the temperature range down to approximately $-9{ }^{\circ} \mathrm{C}$ and a further progress on a maximum value of $1.4 \times 10^{12} \mathrm{~g}^{-1}$. Thus, a linear regression curve was derived for the increase of $n_{\mathrm{m}}$ until the maximum value was reached; it is included in Fig. 2 as a solid green line.

It can be noted from Fig. 1 that bacteria act at the highest temperatures starting not far below $0^{\circ} \mathrm{C}$. Pollen lie in the range of the mineral dust particles. The differences between the mineral dust types are significant, with feldspar being the most efficient one and kaolinite the least efficient one.

\subsubsection{Treatment of immersion freezing in the model}

The previous Eq. (1), which gives the freezing rate of the supercooled drops, had to be replaced by a similar expression that couples the number of active sites and the mass of insoluble particles in the drops. According to the singular description of heterogeneous freezing (Vali, 1971; Broadley et 


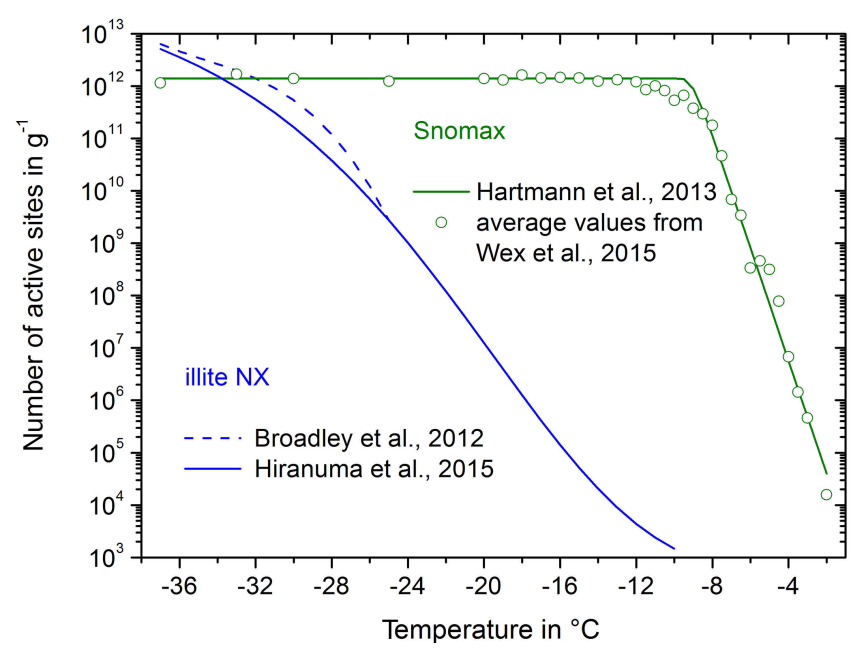

Figure 2. Numbers of active sites per unit mass as a function of temperature. Parameterizations for illite NX and Snomax ${ }^{\circledR}$ based on the outcome of laboratory immersion freezing experiments.

al., 2012), the frozen fraction of drops $f_{\text {ice }}$ is given by

$f_{\text {ice }}(T)=\frac{N_{\mathrm{f}}(T)}{N_{\text {liq }}}=1-\exp \left(-n_{\mathrm{m}}(T) m_{\text {pid }}\right)$,

where $N_{\mathrm{f}}(T)$ is the number of frozen drops at temperature $T, N_{\text {liq }}$ the number of liquid drops, $m_{\text {pid }}$ the mass of particles immersed in the drops, and $n_{\mathrm{m}}(T)$ the number of active sites per unit mass at temperature $T$, which is related to the cumulative nucleus spectrum $K(T)$ per unit mass per unit temperature:

$n_{\mathrm{m}}(T)=\int_{T_{0}}^{T} K(T) \mathrm{d} T$

when lowering the temperature from $T_{0}=0{ }^{\circ} \mathrm{C}$ to $T$. From Eqs. (4) and (5) an expression for the change of the number of frozen drops $\Delta N_{\mathrm{f}}$ per temperature interval $\Delta T$ can be derived (Connolly et al., 2009):

$\Delta N_{\mathrm{f}}=N_{\text {liq }}\left(1-\exp \left(-K(T) m_{\text {pid }} \Delta T\right)\right.$,

where $N_{\text {liq }}$ is the number of supercooled liquid drops and $m_{\text {pid }}$ the mass of particles immersed in the drop. Thus, Eq. (1) can be replaced by

$\frac{\mathrm{d} N_{\mathrm{f}}}{\mathrm{d} t}=N_{\text {liq }} \frac{1-\exp \left(-K(T) m_{\text {pid }} \mathrm{d} T\right)}{\mathrm{d} t}$.

As the aerosol particles are internally mixed, one can assume that only a fraction of the insoluble mass per drop consists of ice nucleating material. Thus, the mass $m_{\text {pid }}$ was reduced by a factor $F_{\mathrm{INP}}$, so that only this mass fraction accounts for possible numbers of active sites $n_{\mathrm{m}}$ and Eq. (7) was modified to

$\frac{\mathrm{d} N_{\mathrm{f}}}{\mathrm{d} t}=N_{\text {liq }} \frac{1-\exp \left(-K(T) m_{\mathrm{pid}} F_{\mathrm{INP}} \mathrm{d} T\right)}{\mathrm{d} t}$.
A similar treatment was applied in Diehl and Wurzler (2010). From Eqs. (2) and (5) it follows that

$K(T)=\frac{\mathrm{d} n_{\mathrm{m}}(T)}{\mathrm{d} T}=b_{\mathrm{imm}} \exp \left(a_{\mathrm{imm}}+b_{\mathrm{imm}} T_{\mathrm{s}}\right)$.

In Eq. (9) the freezing point depression due to the content of soluble material in the drops is considered; for details see Diehl and Wurzler (2004). In the model simulations, immersion freezing starts at the particle-related temperature $T_{\mathrm{ini}}$, and at temperatures below $T_{\mathrm{lim}}$ it is assumed that the numbers of active sites stay constant. The sizes of possibly ice nucleating particles are restricted; i.e., dust particles must be larger than $0.1 \mu \mathrm{m}$ in diameter and bacteria are limited to their typical diameters of 0.3 to $2 \mu \mathrm{m}$ (Matthias-Maser and Jaenicke, 1995). Pollen are large particles of $10 \mu \mathrm{m}$ at least (Straka, 1975); however, for the present simulations a lower limit of $2 \mu \mathrm{m}$ was selected to allow for at least some freezing by pollen (see Sect. 3, initial dry particle number size distributions).

During the model simulations the content of insoluble particles per drop varies by several orders of magnitude, which is due to the sizes of the condensation particles, the uptake of particles by the drops via impaction scavenging, and the drop collisions followed by coalescence. Thus, not all drops of the same sizes freeze at certain temperatures, which describes the situation in real clouds (Diehl and Wurzler, 2004).

\subsection{Contact freezing}

In Diehl et al. (2006) contact freezing was described for several particle types independent of their sizes. However, measurements indicate that the size of the involved particles affects the contact freezing efficiency in the way that efficiency increases with increasing particle size (e.g., Gorbunov et al., 2001; Hoffmann et al., 2013a; Ladino Moreno et al., 2013). Therefore, the description of Diehl et al. (2006) was modified in a way that it is now particle-size dependent.

\subsubsection{Parameterizations based on laboratory data}

Measurements, which give a direct correlation between particle size and contact freezing efficiency, are not yet available for a wider range of ice nucleating particle types. Therefore, for the present parameterization different size classes were examined. Hoffmann et al. (2013a, b), and N. Hoffmann and A. Kiselev (personal communication, 2014) performed contact freezing experiments using an electrodynamical balance with monodisperse particles of 150 to $750 \mathrm{~nm}$ diameter. The results showed rather low median freezing temperatures $T_{50}$ (the temperature where $50 \%$ of an observed drop population freeze), e.g., $-34^{\circ} \mathrm{C}$ for illite $\mathrm{NX},-32.5^{\circ} \mathrm{C}$ for kaolinite Fluka, and less than $-25^{\circ} \mathrm{C}$ for Snomax ${ }^{\circledR}$, in comparison to measurements with polydisperse particle samples.

Those experiments with polydisperse particle samples were performed at the UCLA vertical wind tunnel by Levin 


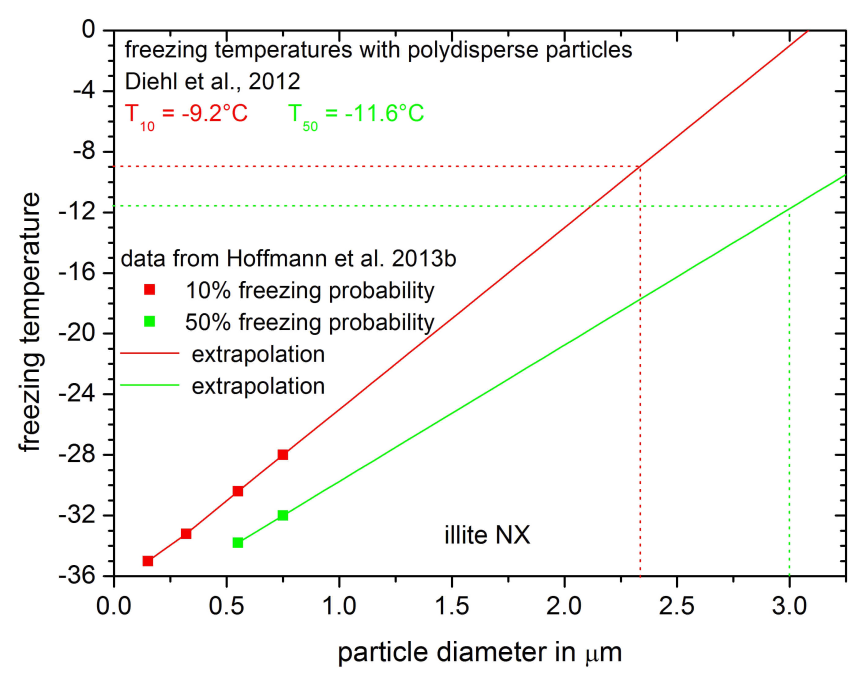

Figure 3. Freezing temperatures as a function of particle diameter for illite NX in the contact mode. Extrapolations to larger particle sizes.

and Yankofsky (1983) and Pitter and Pruppacher (1973). The latter studied kaolinite and montmorillonite with particle diameters between 0.1 and $10 \mu \mathrm{m}$ with a mode between 1 and $2 \mu \mathrm{m}$ and measured median freezing temperatures of -12 and $-8{ }^{\circ} \mathrm{C}$, respectively. Levin and Yankofsky found a median freezing temperature of $-4.5^{\circ} \mathrm{C}$ for bacteria. Diehl et al. (2012) investigated polydisperse mineral particles with supercooled drops suspended in an acoustic levitator. Median freezing temperatures were $-11.5^{\circ} \mathrm{C}$ for illite $\mathrm{NX}$ and $-8.7^{\circ} \mathrm{C}$ for montmorillonite $\mathrm{K} 10$. The latter agrees very well with the value found by Pitter and Pruppacher (1973) within the measurement error $(1 \mathrm{~K})$. Extrapolating the data of Hoffmann et al. (2013b) for illite NX towards larger particle sizes as shown in Fig. 3 indicates that a median freezing temperature of $-11.5^{\circ} \mathrm{C}$ could be affected by dust particles with sizes between 2.3 and $3.0 \mu \mathrm{m}$ in diameter (Diehl et al., 2012). Those particles are part of the polydisperse particle spectrum of illite NX (Hiranuma et al., 2015). Thus, one might conclude that the median freezing temperatures determined for polydisperse particle samples are affected by larger particles present in the size spectrum. This is probably the case also for previous findings measured with polydisperse particle samples.

Therefore, as an approximation, data obtained from polydisperse particle samples were used in the present parameterizations for particles with diameters mostly larger than $1 \mu \mathrm{m}$, and at least larger than $0.7 \mu \mathrm{m}$. Data obtained from monodisperse particle samples were taken for ranges around the respective particle sizes.

The experimental data used as basis for the parameterizations include the following ice nucleating particle types: bacteria, feldspar, montmorillonite, illite, and kaolinite. In most cases, a linear correlation between the frozen fraction of

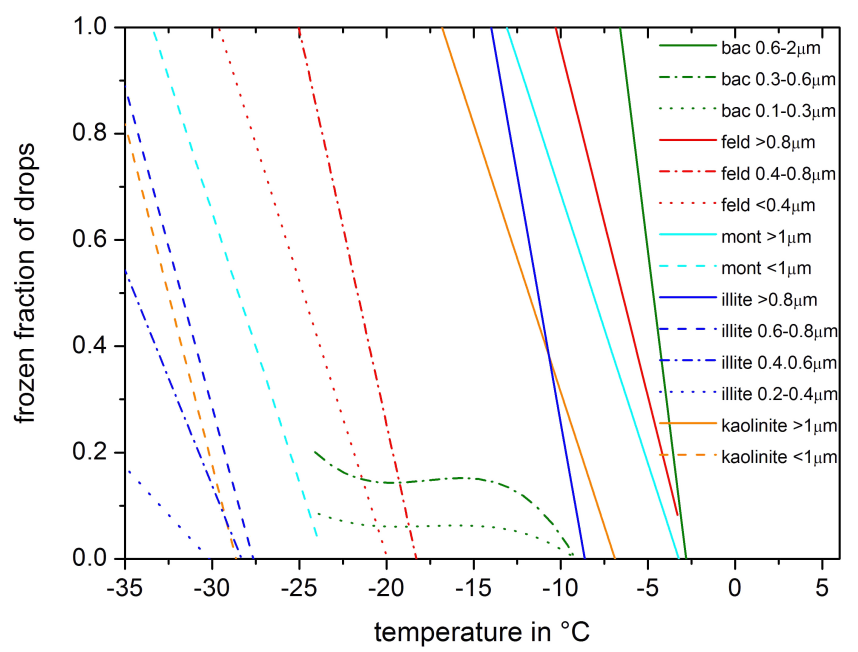

Figure 4. Frozen fraction of drops by contact freezing as a function of temperature for various particle types and sizes, marked by different colors and line styles. Calculated by Eqs. (10) and (11), respectively, with constants given in Tables 2 and 3 for various particle types, based on the outcome of laboratory experiments (Pitter and Pruppacher, 1973; Levin and Yankofsky, 1983; Diehl et al., 2012; Hoffmann et al., 2013a, b; N. Hoffmann and A. Kiselev, personal communication, 2014; K. Diehl and S. K. Mitra, personal communication, 2014).

Table 2. Values of contact freezing constants in Eqs. (10) and (11). Based on data from ${ }^{\text {a }}$ N. Hoffmann and A. Kiselev (personal communication, 2014), who used Snomax ${ }^{\circledR}$ as a proxy for bacteria and b Levin and Yankofsky (1983). The latter values were used in Diehl et al. (2006).

\begin{tabular}{lrrrr}
\hline Particle type and size & $a_{\text {con }}$ & $b_{1, \text { con }}$ & $b_{2, \text { con }}$ & $b_{3, \text { con }}$ \\
\hline \multicolumn{5}{c}{ Bacteria } \\
\hline $0.3 \mu \mathrm{m} \leq d_{\text {ap }}<0.5 \mu \mathrm{m}^{\mathrm{a}}$ & -1.36581 & -0.26367 & -0.01511 & -2.84911 \\
$0.5 \mu \mathrm{m} \leq d_{\text {ap }}<0.7 \mu \mathrm{m}^{\mathrm{a}}$ & -0.55381 & -0.10712 & -0.00616 & -1.16822 \\
\hline \multicolumn{5}{c}{$a_{\text {con }}$} \\
\hline $0.7 \mu \mathrm{m} \leq d_{\text {ap }}<2 \mu \mathrm{m}^{\mathrm{b}}$ & -0.264 & -0.742 \\
\hline
\end{tabular}

drops and the temperature was found. From the experimental data, regression lines were calculated, which are shown in Fig. 4 for various particle types (marked by different colors) and particle sizes (marked by different line styles).

\section{Bacteria}

Particle sizes of bacteria were restricted to their typical sizes with diameters between 0.3 and $2 \mu \mathrm{m}$ (Matthias-Maser and Jaenicke, 1995). Measurements of N. Hoffmann and A. Kiselev (personal communication, 2014) were performed with monodisperse Snomax ${ }^{\circledR}$ particles of 0.32 and $0.55 \mu \mathrm{m}$ diameter. These data were used for size ranges from 0.3 to $0.5 \mu \mathrm{m}$ and from 0.5 to $0.7 \mu \mathrm{m}$. For particles between 0.7 and $2 \mu \mathrm{m}$ 
Table 3. Values of contact freezing constants in Eq. (10). Based on data from ${ }^{\mathrm{a}}$ Hoffmann et al. (2013b); ${ }^{\mathrm{b}}$ Diehl et al. (2012); ${ }^{\mathrm{c}}$ Extrapolation; ${ }^{\mathrm{d}}$ and ${ }^{\mathrm{f}}$ Pitter and Pruppacher (1973), used in Diehl et al. (2006); ${ }^{\mathrm{d}}$ Hoffmann et al. (2013a); ${ }^{\mathrm{g}}$ N. Hoffmann and A. Kiselev (personal communication, 2014); ${ }^{\mathrm{h}} \mathrm{K}$. Diehl and S. K. Mitra (personal communication, 2014).

\begin{tabular}{lcc}
\hline Particle type and size & $a_{\text {con }}$ & $b_{\text {con }}$ \\
\hline Illite & & \\
\hline $0.1 \mu \mathrm{m}<d_{\mathrm{ap}} \leq 0.2 \mu \mathrm{m}^{\mathrm{a}}$ & -0.0306 & -0.9980 \\
$0.2 \mu \mathrm{m}<d_{\mathrm{ap}} \leq 0.4 \mu \mathrm{m}^{\mathrm{a}}$ & -0.0359 & -1.0838 \\
$0.4 \mu \mathrm{m}<d_{\mathrm{ap}} \leq 0.6 \mu \mathrm{m}^{\mathrm{a}}$ & -0.0812 & -2.2989 \\
$0.6 \mu \mathrm{m}<d_{\mathrm{ap}} \leq 0.8 \mu \mathrm{m}^{\mathrm{a}}$ & -0.1210 & -3.3452 \\
$0.8 \mu \mathrm{m}<d_{\mathrm{ap}}$ & $-0.1863^{\mathrm{b}}$ & -1.6076 \\
\hline Montmorillonite & & \\
\hline $0.1 \mu \mathrm{m}<d_{\mathrm{ap}} \leq 1 \mu \mathrm{m}^{\mathrm{c}}$ & -0.1014 & -2.3899 \\
$1 \mu \mathrm{m}<d_{\mathrm{ap}}$ & -0.1014 & -0.3277 \\
\hline Kaolinite & & \\
\hline $0.1<d_{\mathrm{ap}} \leq 1 \mu \mathrm{m}^{\mathrm{e}}$ & -0.1285 & -3.6792 \\
$1 \mu \mathrm{m}<d_{\mathrm{ap}}^{\mathrm{f}}$ & -0.1007 & -0.6935 \\
\hline Feldspar & & \\
\hline $0.1<d_{\mathrm{ap}} \leq 0.4 \mu \mathrm{m}^{\mathrm{g}}$ & -0.1033 & -2.0585 \\
$0.4<d_{\mathrm{ap}}<0.8 \mu \mathrm{m}^{\mathrm{g}}$ & -0.1484 & -2.7154 \\
$0.8 \mu \mathrm{m}<d_{\mathrm{ap}} \mathrm{h}$ & -0.34964 & -0.13095 \\
\hline
\end{tabular}

the data of Levin and Yankofsky (1983) were taken. The results are given in Fig. 4 as green lines.

\section{Mineral dust particles}

For mineral dust particles, a lower size limit of $0.1 \mu \mathrm{m}$ in diameter was assumed. Illite NX particles were investigated by Hoffmann et al. (2013b) with $0.15,0.32,0.55$, and $0.75 \mu \mathrm{m}$ particles. These data were taken for size ranges from 0.1 to $0.2 \mu \mathrm{m}, 0.2$ to $0.4 \mu \mathrm{m}, 0.4$ to $0.6 \mu \mathrm{m}$, and 0.6 to $0.8 \mu \mathrm{m}$. For larger particles, data from Diehl et al. (2012) were used. The results are shown in Fig. 4 as blue lines. K-feldspar was investigated by N. Hoffmann and A. Kiselev (personal communication, 2014) with 0.32 and $0.55 \mu \mathrm{m}$ particles and by K. Diehl and S. K. Mitra (personal communication, 2014) with polydisperse particles. Here three size ranges were defined, from 0.1 to $0.4,0.4$ to $0.8 \mu \mathrm{m}$, and larger than $0.8 \mu \mathrm{m}$. The data are marked in Fig. 4 as red lines. For kaolinite and montmorillonite, two size ranges were also specified, from 0.1 and $1 \mu \mathrm{m}$ and larger than $1 \mu \mathrm{m}$. The data for the larger particles sizes were both taken from Pitter and Pruppacher (1973; polydisperse particle samples). Results from Hoffmann et al. (2013a) were used for the smaller size range of kaolinite. Under the assumption that the differences between larger and smaller ice nucleating particles (INP) are similar for kaolinite and montmorillonite the data for the smaller size range of montmorillonite were obtained by a parallel shifting analogue to kaolinite. In Fig. 4, results for kaolinite are given in orange, results for montmorillonite in cyan.

From Fig. 4 it can be noted that particles in the larger size ranges affect freezing already at temperatures around $-10^{\circ} \mathrm{C}$, while smaller particles become active in a temperature range around $-25^{\circ} \mathrm{C}$. Bacteria act at the highest temperatures, and kaolinite and illite at the lowest. For all particle types and sizes except bacteria smaller than $0.7 \mu \mathrm{m}$, the frozen fraction of drops increases linearly with temperature $T$ (given in ${ }^{\circ} \mathrm{C}$ ) according to Diehl et al. (2006):

$\frac{N_{\mathrm{f}}}{N_{\text {liq }}}=a_{\text {con }} T+b_{\text {con }}$,

where $N_{\mathrm{f}}$ is the number of frozen drops, $N_{\text {liq }}$ the number of liquid drops colliding with inactivated particles at temperature $T$, and the constants $a_{\text {con }}$ and $b_{\text {con. Note that in Eq. (10) }}$ the frozen fraction is limited to values between 0 and 1 . In Diehl et al. (2006), the constants were given for several particle types independent of their sizes, while in the present parameterization the constants $a_{\text {con }}$ and $b_{\text {con }}$ are size resolved. They are listed in Tables 2 and 3. In the case of small bacteria, the equation to calculate the frozen fraction of drops with respect to the temperature $T$ (in ${ }^{\circ} \mathrm{C}$ ) has the form

$\frac{N_{\mathrm{f}}}{N_{\mathrm{liq}}}=a_{\mathrm{con}}+b_{1, \mathrm{con}} T+b_{2, \mathrm{con}} T^{2}+b_{3, \mathrm{con}} T^{3}$.

The size-resolved constants $a_{\text {con }}, b_{1, \text { con }}, b_{2, \text { con }}$, and $b_{3 \text {,con }}$ are given in Table 2.

\subsubsection{Treatment of contact freezing in the model}

The description of contact freezing includes the following conditions: (1) inactivated particles have to be present, and (2) particles and supercooled drops have to collide with each other. Furthermore, the sizes of the particles allowed as activating ice nucleating particles are restricted as for deposition freezing (i.e., dust particles $>0.1 \mu \mathrm{m}$ in diameter, bacteria 0.3 to $2 \mu \mathrm{m}$ in diameter).

The presence of inactivated particles is always the case during the air parcel ascent because of entrainment; i.e., new inactivated particles are continuously mixed in at the edges of the simulated cloud. However, in the presently employed air parcel model the particles are in equilibrium with respect to the water vapor in their environment and, thus, they take up some water due to their size and soluble fraction. As introduced in Diehl et al. (2006) the dryness of a potential ice nucleating particle is defined by the assumption that the water mass should be smaller than half of the dry particle mass.

The second condition is considered by a collision kernel $K$ calculated for supercooled drops and particles (Kerkweg et al., 2003; for more details see Diehl et al., 2006):

$$
K=E_{\text {coll }}\left|V_{\infty, \text { drop }}-V_{\infty, \text { ap }}\right| \cdot \pi\left(r_{\text {drop }}-r_{\infty}\right)^{2},
$$


where $V_{\infty \text {,drop }}$ and $V_{\infty \text {,ap }}$ are the terminal velocities of the drop and the particle, respectively, and $r_{\text {drop }}$ and $r_{\text {ap }}$ the drop and particle radii, respectively. The collision kernel shows the highest values for collisions between large drops and particles (Diehl et al., 2006); i.e., contact freezing is most efficient when large supercooled drops and particles are present. If during the model simulations inactivated particles collide with supercooled drops, the number of frozen drops is calculated. It is assumed that only a fraction $F_{\text {INP }}$ of the aerosol particles is able to act as ice nucleating particles. Only drops that collide with those INP are allowed to freeze, which is included in the following modified Eqs. (13) and (14):

$N_{\mathrm{f}}=F_{\mathrm{INP}} N_{\text {liq }}\left(a_{\mathrm{con}} T+b_{\text {con }}\right)$,

$N_{\mathrm{f}}=F_{\mathrm{INP}} N_{\text {liq }}\left(a_{\text {con }}+b_{1, \mathrm{con}} T+b_{2, \mathrm{con}} T^{2}+b_{3, \mathrm{con}} T^{3}\right)$.

This is under the requirement that these equations are based on measurements with one drop-particle collision per freezing event so that the fraction of frozen drops in Eqs. (13) and (14) can be set equal to the freezing probability (Ladino Moreno et al., 2013). This requirement is fully achieved in the experiments of Hoffmann et al. (2013a, b), and N. Hoffmann and A. Kiselev (personal communication, 2014). During the experiments of Pitter and Pruppacher (1973), Levin and Yankofsky (1983), and Diehl et al. (2012) the number of collisions per freezing event is not documented. Single supercooled drops were freely levitated (in a wind tunnel or an acoustic levitator) while one burst of INP was blown on it. Therefore, as the particles collided almost simultaneously with the supercooled drop, one could assume that in case the drop froze this was triggered by the first collision.

\subsection{Deposition freezing}

\subsubsection{Parameterizations based on laboratory data}

The experimental data used as basis include the following ice nucleating particle types: bacteria, feldspar, illite, and Saharan and Asian dust. The measurements were performed with INP counters FRIDGE (FRankfurt Immersion and Deposition freezinG Experiment) or with a continuous flow diffusion chamber (CFDC). Data for Asian and Saharan dust were taken from measurements with the FRIDGETAU (FRankfurt Ice-nuclei Deposition freezinG Experiment, the Tel Aviv University version) (K. Ardon-Dryer and Z. Levin, personal communication, 2012), data for illite NX and Snomax ${ }^{\circledR}$ from INUIT FRIDGE experiments (Hiranuma et al., 2015; A. Danielczok and H. Bingemer, personal communication, 2014; Weber, 2014), and data for illite IMt1 and Kfeldspar from CFDC measurements (Yakobi-Hancock et al., 2013). The Snomax ${ }^{\circledR}$ data were considered as representative for bacteria in the model simulations.

K. Ardon-Dryer and Z. Levin (personal communication, 2012) measured the activation of Saharan and Asian dust particles at different ice supersaturations and temperatures and

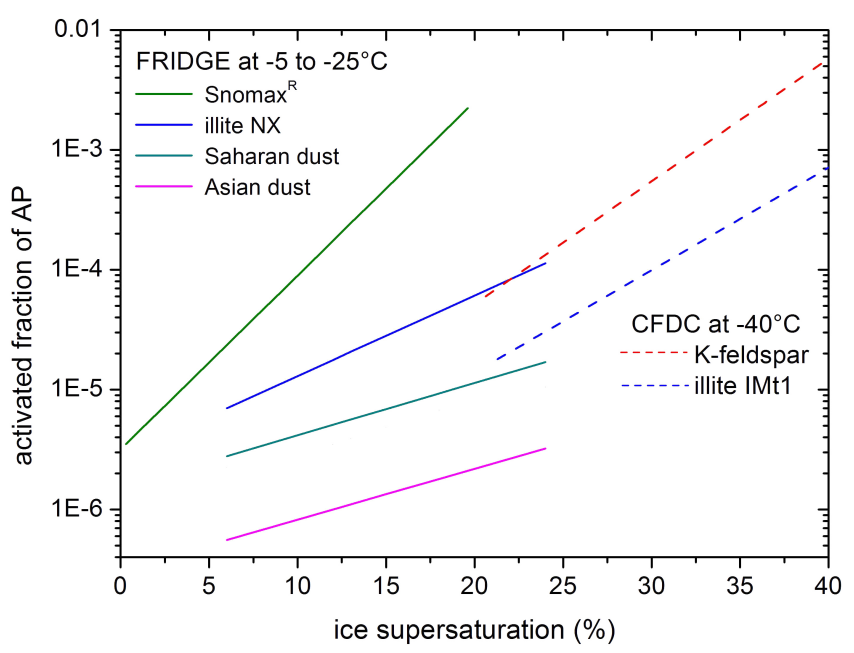

Figure 5. Activated fraction of particles in the deposition freezing mode as a function of ice supersaturation for Saharan and Asian dust. Data from K. Ardon-Dryer and Z. Levin (personal communication, 2012).

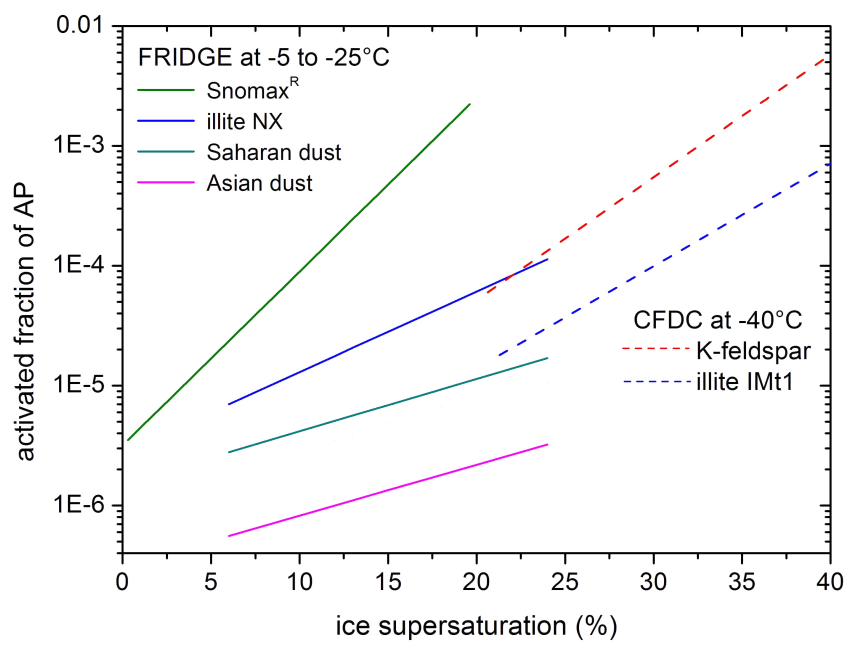

Figure 6. Activated fraction of particles in the deposition freezing mode as a function of ice supersaturation for various particle types. Regression lines based on data from K. Ardon-Dryer and Z. Levin (personal communication, 2012; Saharan and Asian dust), YakobiHancock et al. (2013; K-feldspar and illite IMt1), A. Danielczok and H. Bingemer (personal communication, 2014; Snomax ${ }^{\circledR}$ and illite NX). Described by Eq. (15) with constants in Table 4.

observed an increase of the activated particles with supersaturation but no temperature dependence in the observed temperature range between -15 and $-20^{\circ} \mathrm{C}$. Figure 5 shows the data of K. Ardon-Dryer and Z. Levin (personal communication, 2012) as activated fraction of particles as a function of ice supersaturation. From all data, mean values were calculated and regression lines were derived. These are included in Fig. 6 as cyan and pink solid lines. 
The INUIT FRIDGE measurements were performed with illite NX and Snomax ${ }^{\circledR}$ in a temperature range from -10 to $-25^{\circ} \mathrm{C}$. A significant temperature dependence was not observed and, therefore, the activated particle fraction was derived as a function of ice supersaturation only. As ice saturation is dependent on temperature, an implicit dependence of deposition freezing on temperature is already incorporated. Regression lines were calculated based on the average values. They are given in Fig. 6 as blue (illite NX) and green (Snomax ${ }^{\circledR}$ ) solid lines. It can be noticed that illite NX is much more efficient than the Saharan and Asian dust particles, which are characterized by a mixed composition. Asian dust mostly consists of quartz (Möhler et al., 2006), which acts in the deposition mode at lower temperatures than illite (Zimmermann et al., 2008). Also Saharan dust contains a quartz fraction of nearly one-third (Möhler et al., 2006). As expected the activated fractions of Snomax ${ }^{\circledR}$ particles are the highest. Measurements with a CFDC were performed at $-40{ }^{\circ} \mathrm{C}$ with illite IMt1 and K-feldspar particles (YakobiHancock et al., 2013). Regression lines were derived from the data and are given in Fig. 6 as blue (illite IMt1) and red (K-feldspar) broken lines, respectively.

For illite NX and Snomax ${ }^{\circledR}$, data are available not only for polydisperse particle samples but also for samples with distinct particle sizes (A. Danielczok and H. Bingemer, personal communication, 2014; Weber, 2014). In case of illite, monodisperse particles with diameters of 300 and $500 \mathrm{~nm}$ resulted in higher activated fractions for the larger particle sizes, but in both cases the activated fractions were higher than in case of the polydisperse particle samples. In case of Snomax ${ }^{\circledR}$, monodisperse particles of 100, 200, 300, and $500 \mathrm{~nm}$ were investigated finding again higher activated fractions for the larger particle sizes than in the polydisperse case. As particle-size-resolved measurements are not available for all particle types it was decided to treat deposition freezing size independent in the model. As the activated fractions of the polydisperse particle samples (which are the basis of the present parameterizations) are lower than the ones of monodisperse samples, this would not lead to an overestimation of deposition freezing.

For all particle types, an exponential increase of the activated fraction with the ice supersaturation was found, which is described by

$$
\frac{N_{\text {act }}}{N_{\text {total }}}=\exp \left(a_{\text {dep }}+b_{\text {dep }} s_{\text {ice }}\right),
$$

where $N_{\text {act }}$ is the number of activated particles, $N_{\text {total }}$ the total particle number, $s_{\text {ice }}$ the ice supersaturation given in $\%$, and $a_{\text {dep }}$ and $b_{\text {dep }}$ are particle-related constants. The values of $a_{\text {dep }}$ and $b_{\text {dep }}$ are listed in Table 4 for the different particle types. Note that the activated fraction in Eq. (15) is limited to values between 0 and 1 .

Although data were available only for ice supersaturation ranges below $25 \%$ (bacteria, illite NX, Saharan and Asian dust) and above $20 \%$ (illite IMt1 and feldspar), respectively,
Table 4. Values of deposition freezing constants $a_{\mathrm{dep}}$ and $b_{\mathrm{dep}}$ in Eq. (15) and values of lower limits of temperature $T_{\text {ini }}$ and ice supersaturation $s_{\text {ice,ini }}$. Based on data from ${ }^{\text {a }}$ A. Danielczok and $\mathrm{H}$. Bingemer (personal communication, 2014), ${ }^{b}$ Yakobi-Hancock et al. (2013), and ${ }^{c}$ K. Ardon-Dryer and Z. Levin (personal communication, 2012).

\begin{tabular}{lrrrr}
\hline Particle type & $a_{\text {dep }}$ & $b_{\text {dep }}$ & $\begin{array}{r}T_{\text {ini }} \\
{ }^{\circ} \mathrm{C}\end{array}$ & $\begin{array}{r}s_{\text {ice, ini }} \\
\%\end{array}$ \\
\hline Bacteria $^{\mathrm{a}}$ & -12.65977 & 0.33382 & $-10^{\mathrm{a}}$ & $3^{\mathrm{a}}$ \\
Feldspar $^{\mathrm{b}}$ & -14.58404 & 0.23576 & $-13^{\mathrm{a}}$ & $6^{\mathrm{a}}$ \\
${\text { Illite } 1^{\mathrm{a}}}^{\text {Illite 2 }}$ & -12.79648 & 0.15451 & $-13^{\mathrm{a}}$ & $6^{\mathrm{a}}$ \\
Saharan dust $^{\mathrm{c}}$ & -15.11871 & 0.19669 & $-13^{\mathrm{a}}$ & $6^{\mathrm{a}}$ \\
Asian dust $^{\mathrm{c}}$ & -13.39669 & 0.10058 & $-18^{\mathrm{c}}$ & $11^{\mathrm{c}}$ \\
\hline
\end{tabular}

due to the investigated temperature ranges, it is assumed that Eq. (15) is valid for the complete ice supersaturation range. However, according to the onset of deposition freezing in the experiments, lower limits of ice supersaturation and temperature as measured during the FRIDGE experiments were set in the model. That means, deposition freezing of illite IMt1 and feldspar start at the same conditions as illite NX. In the model simulations, the two types of illite were taken as upper and lower limits and referred to as illite 1 and illite 2 . The values are given in Table 4.

\subsubsection{Treatment of deposition freezing in the model}

Conditions for deposition freezing are (1) inactivated particles have to be present as it is required for contact freezing; i.e., the same particles may affect deposition or contact freezing. Additionally, (2) there are two size conditions. First, the inactivated particles have to exceed a critical germ size $r^{*}$, depending on temperature and ice supersaturation, which is according to Pruppacher and Klett (2010):

$r^{*}=\frac{2 M_{\mathrm{W}} \sigma_{i, v}}{R T \rho_{\text {ice }} \ln S_{\text {ice }}}$,

where $M_{\mathrm{W}}$ is the molecular weight of water, $\sigma_{i, v}$ the surface tension, $R$ the universal gas constant, $T$ the temperature, $\rho_{\text {ice }}$ the density of ice, and $S_{\text {ice }}$ the ice saturation ratio. However, this condition is actually redundant as it excludes particles smaller than approximately $0.01 \mu \mathrm{m}$ and, additionally, size restrictions of the ice nucleating particles were assumed: dust particles larger than $0.1 \mu \mathrm{m}$ in diameter and bacteria between their typical size range of 0.3 and $2 \mu \mathrm{m}$ in diameter (MatthiasMaser and Jaenicke, 1995).

In each time step it is checked if temperature and ice supersaturation are above the limit values $T_{\text {ini }}$ and $s_{\text {ice,ini }}$, if yes it is checked which available inactivated particles exceed the size limits, and from these the activated fraction is calculated. It is assumed that only a part $F_{\text {INP }}$ of the available particles is able to act as ice nucleating particles. Therefore, the total 


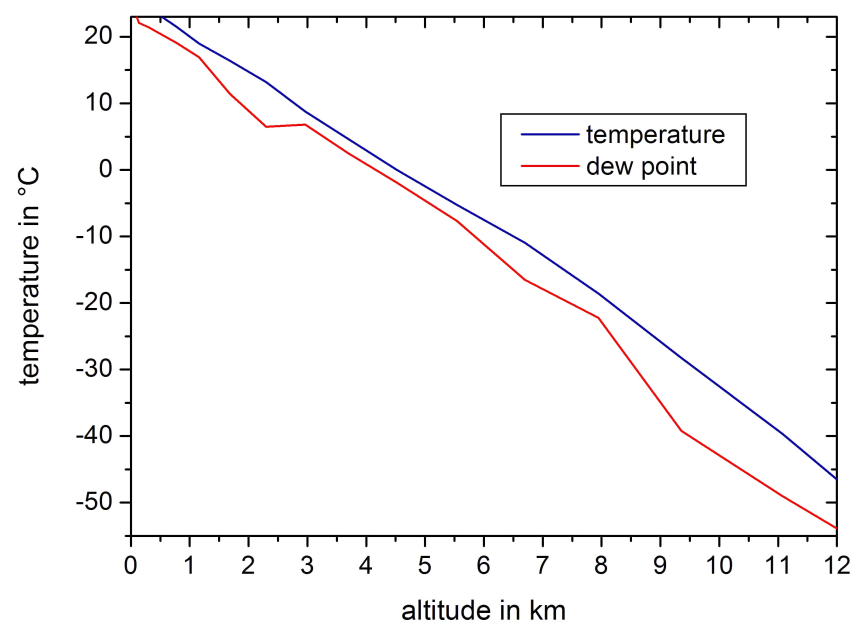

Figure 7. Development of temperature and dew point with altitude during simulations with the air parcel model (B. Langmann, personal communication, 2004).

number of particles in Eq. (15) is reduced:

$N_{\text {act }}=F_{\text {INP }} N_{\text {total }} \exp \left(a_{\text {dep }}+b_{\text {dep }} s_{\text {ice }}\right)$.

The activated particles are moved to the ice particle spectrum and grow further by water vapor deposition and they may serve as germs for secondary ice formation; i.e., they may initiate freezing of supercooled drops by collision (Diehl et al., 2006).

\section{Model initiation and sensitivity studies}

During the present sensitivity studies, convective clouds were simulated. In those clouds liquid drops are transferred into higher regions in the atmosphere and supercooled. Once frozen the ice particles grow further by riming (i.e., collision with other supercooled droplets) and by the deposition of water vapor (i.e., at the expense of liquid drops, the BergeronFindeisen process, which is typically much faster than condensation). Due to the vertical velocity, large precipitationsized ice particles can form in convective clouds and fall out as graupel, hailstones, or (when they fall through the melting layer) as large raindrops. The present model simulations were initialized with a convective vertical profile where temperatures in higher altitudes were low enough to assure ice formation. It has an average lapse rate of approximately $0.6 \mathrm{~K}$ per $100 \mathrm{~m}$ without any maxima or minima (B. Langmann, personal communication, 2004); see Fig. 7.

The ascent of the air parcel is driven by a temperature difference between the air bubble and its environment. Depending on the temperature difference, the updraft of the air parcel proceeds at various speeds and reaches various heights with corresponding temperatures (Diehl et al., 2006). For the present simulations, the final temperatures were $-24.5,-29$, and $-40{ }^{\circ} \mathrm{C}$ with corresponding maximum altitudes of $9,9.5$,

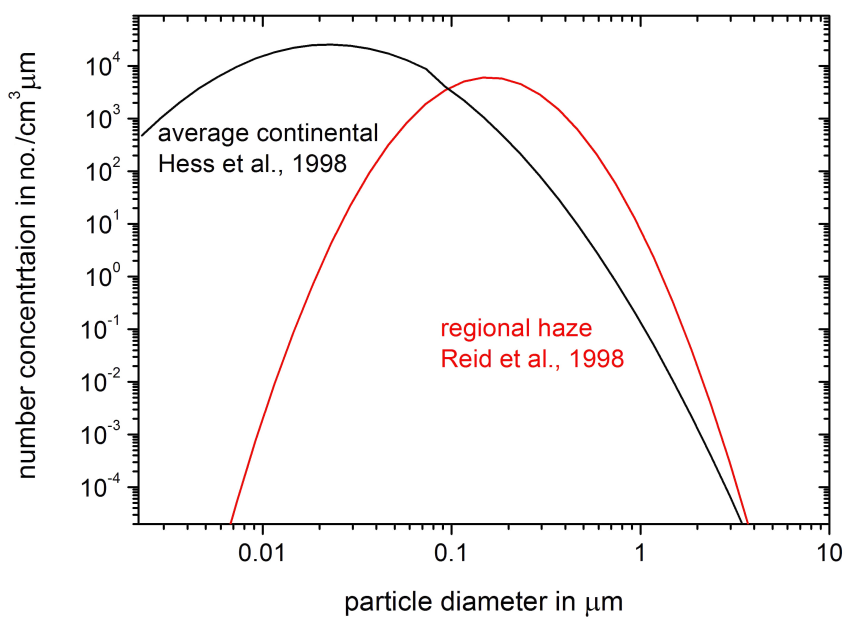

Figure 8. Initial dry aerosol particle number size distributions: Number concentrations per $\mathrm{cm}^{3}$ and $\mu \mathrm{m}$ as a function of particle diameter.

and $11 \mathrm{~km}$; the maximum vertical velocities during the ascent of the parcel were $15,16.5$, and $19 \mathrm{~m} \mathrm{~s}^{-1}$.

Two different dry aerosol particle number size distributions were used to compare the effects on ice formation. One was an average continental distribution (OPAC database; Hess et al., 1998), which is a rather broad spectrum and characterized by a large number of small particles (see black line in Fig. 8); its parameters are $N=7000 \mathrm{~cm}^{-3}, d=42.4 \mathrm{~nm}$, and $\sigma=2.24$ (with $N$ the particle number, $\mathrm{d}$ the diameter, and $\sigma$ the standard deviation). The other one was a regional haze distribution (Reid et al., 1998), which is a rather narrow spectrum and characterized by larger particle sizes. The parameters are $N=6000 \mathrm{~cm}^{-3}, d=0.1 \mu \mathrm{m}$, and $\sigma=1.65$; see red line in Fig. 8. Both rather simple mono-modal distributions were selected to avoid a mixture of effects due to ice physics and activation of aerosol particles. Thus, the effects of ice physics should be emphasized. The soluble fraction $\varepsilon$ of the aerosol particles was set to 0.5 , which is a typical value of atmospheric particles (Busch et al., 2002).

Regarding the conditions on the sizes of the ice nucleating particles as given in Sect. 2 (mineral dust particles larger than $0.1 \mu \mathrm{m}$, bacteria larger than $0.3 \mu \mathrm{m}$, pollen larger than $2 \mu \mathrm{m})$, one can conclude from Fig. 8 that - in particular in the average continental case - the majority of the continental particles is too small to affect ice formation. The dry particle spectrum influences the drop spectrum, which is important for immersion and contact modes. Figure 9 shows the number concentrations as a function of diameter for two different altitudes and corresponding temperatures of zero and $-29^{\circ} \mathrm{C}$ for the two cases: average continental and regional haze particles. Because the liquid water content is the same during both model simulations, fewer but larger drops develop with the regional haze distribution and numerous but smaller drops with average continental distribution. On 
the other hand, as the continental spectrum is broader, collision and coalescence processes are more effective and, thus, larger drops evolve. Also given in Fig. 9 are the number concentrations of the interstitial aerosol particles. Note that during the updraft inactivated aerosol particles are available for ice formation in deposition contact modes.

With these initial conditions, a multitude of sensitivity studies was performed to demonstrate the impact of ice nuclei concentrations and types on ice formation in convective mixed-phase clouds. First, single freezing processes were studied while the following parameters were varied:

- dry aerosol particle number size distribution: average continental and regional haze;

- ice nucleating particle type - biological particles and mineral dust;

- temperature difference: 3,2 , and $1.5 \mathrm{~K}$, leading to final temperatures of $-40,-29$, and $-24.5^{\circ} \mathrm{C}$, respectively;

- fraction of potential ice nucleating particles $F_{\mathrm{INP}}$ - variation between 0.001 and $10 \%$.

Afterwards, coupled freezing processes were investigated to study the competition between the different freezing processes. These were undertaken only with those parameters that resulted in higher ice formation.

\section{Results and discussion}

\subsection{Ice water fractions and single freezing processes}

To evaluate the efficiency of the different freezing processes and ice nucleating particle types, as a central diagnostic parameter the ice water fraction IWF was selected, which is calculated from the ice water content IWC and the liquid water content LWC:

$\mathrm{IWF}=\frac{\mathrm{IWC}}{\mathrm{LWC}+\mathrm{IWC}}$.

According to Korolev et al. (2003) an ice cloud is defined by IWF $>0.9$, a liquid cloud by IWF $<0.1$, and mixed-phase clouds by $0.1 \leq \mathrm{IWF} \leq 0.9$. Note that in an air parcel model, the IWF is only influenced by in situ ice formation processes and not by sedimentation of ice into or out of the considered parcel. In the following Tables 5 to 7 , the ice water fractions as results from the sensitivity studies are listed for immersion, contact, and deposition freezing. Ice and mixed-phase clouds are marked by bold face type.

Tables 5-7 show that mixed-phase or ice clouds mainly evolved from the continental particle distribution with bacteria, feldspar, or illite INP and with larger $\Delta T$, i.e., final temperatures reaching below $-25^{\circ} \mathrm{C}$. The different points are discussed in detail in the following.

\subsubsection{Particle number size distributions}

With the regional haze particles (larger particles but smaller numbers), less ice was formed in most cases than with the average continental particles (smaller particles but larger number). Less but mostly large drops develop with the regional haze distribution and many but smaller drops with average continental distribution (see Fig. 9). On the other hand, a few still larger drops evolved from the tail of the continental spectrum. The presence of large drops favors immersion and contact freezing (immersion mode: the drops contain more insoluble material; contact mode: the collision kernel between large drops and particles is enhanced); see Tables 5 and 6. This was suggested already by the findings of Diehl et al. (2006) and confirmed by, e.g., Lance et al. (2011), who concluded from their observations that the drop size distribution modulates ice processes in mixed-phase clouds.

In the deposition mode (Table 7) not the drops but the interstitial particles are relevant. More inactivated particles are present in the regional haze case than in the continental case (see Fig. 9), so that because of the higher competition between the many particles, less ice particles develop by the deposition of water vapor.

\subsubsection{Freezing modes}

Immersion freezing affects the most mixed-phase clouds with ice water fractions of more than 0.5 and even ice clouds with all kinds of investigated INP (Table 5). Pollen are, of course, disadvantaged because of their large size, kaolinite particles are the less efficient mineral dust particles while bacteria and feldspar are the most efficient INP. With bacteria, freezing occurred already with potential fractions of INP $F_{\text {INP }}$ as low as $0.001 \%$. With mineral dust, potential fractions of INP $F_{\text {INP }}$ of $0.01 \%$ (feldspar, illite) or $0.1 \%$ (kaolinite) were necessary. Ice formation was sensitive to the type of mineral dust as well as to the potential fraction of INP. For instance, under the same conditions an ice cloud could form with feldspar but a mixed-phase cloud with only a small ice water fraction with kaolinite.

In the contact mode, there is very little ice formation (Table 6). Only liquid clouds formed with the regional haze particle distribution, but in case of the average continental distribution at least some mixed-phase clouds formed with ice water fractions between 0.1 and 0.3 . High potential fractions of INP $F_{\text {INP }}$ of $10 \%$ were required. Bacteria did not affect ice formation, this probably results from the restricted particle sizes. The type of mineral dust decides whether mixed-phase clouds are formed (feldspar, montmorillonite) or not (illite, kaolinite).

Effective deposition INP are bacteria, feldspar, and illite while the mixed particle samples Saharan and Asian dust form liquid clouds only. Mixed-phase clouds formed with high potential INP fractions $F_{\text {INP }}$ between 1 and $10 \%$. The results for the different mineral dust types are rather simi- 

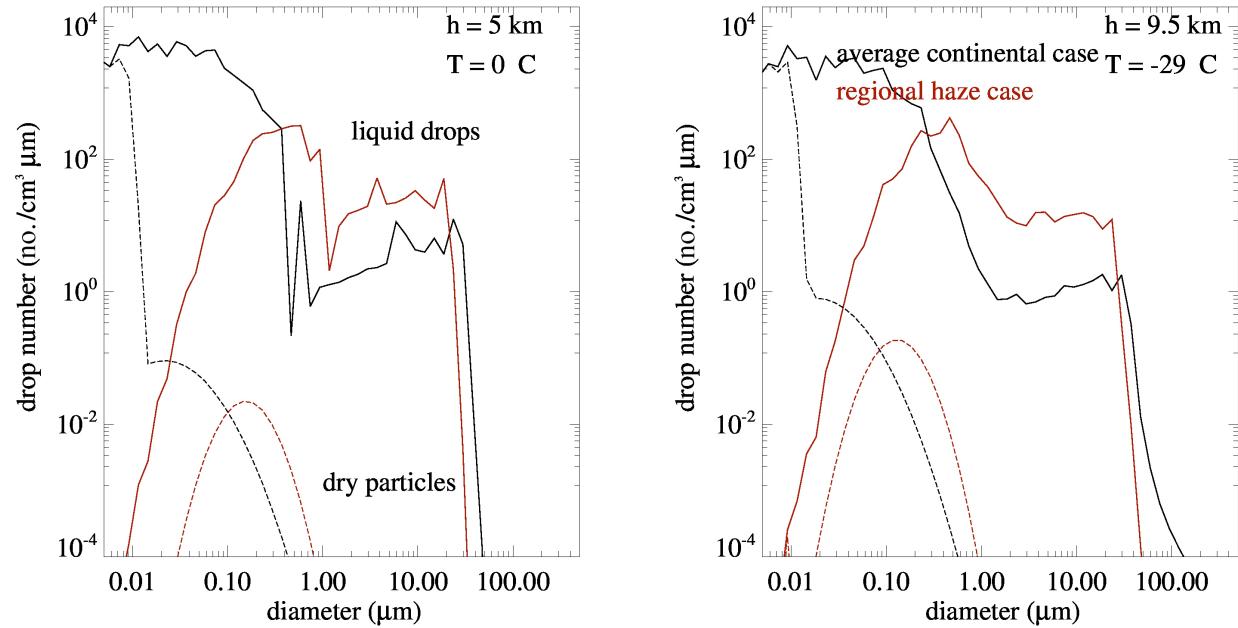

Figure 9. Results from model runs without freezing. Development of liquid drop (solid lines) and interstitial particle numbers (dashed lines) with altitude for two initial aerosol particle number size distributions: average continental (black lines), regional haze (red lines), with $\Delta T=2 \mathrm{~K}$. Number concentrations per $\mathrm{cm}^{3}$ and $\mu \mathrm{m}$ as a function of particle diameter.

Table 5. Ice water fractions from sensitivity studies with immersion freezing. Liquid clouds: IWF $<0.1$, mixed-phase clouds: $0.1 \leq$ IWF $\leq 0.9$, and ice clouds: IWF $>0.9$. Cases referring to mixed-phase clouds and ice clouds are written in bold.

\begin{tabular}{|c|c|c|c|c|c|c|c|c|c|c|}
\hline \multicolumn{11}{|c|}{ Immersion freezing } \\
\hline \multirow{2}{*}{$\begin{array}{l}\mathrm{AP} \\
F_{\mathrm{INP}}(\%)\end{array}$} & \multicolumn{5}{|c|}{ Regional haze } & \multicolumn{5}{|c|}{ Average continental } \\
\hline & 0.001 & 0.01 & 0.1 & 1 & 10 & 0.001 & 0.01 & 0.1 & 1 & 10 \\
\hline \multicolumn{11}{|c|}{$\mathrm{d} T=3 \mathrm{~K} T_{\text {fin }}=-40^{\circ} \mathrm{C}$} \\
\hline Bacteria & 0.27 & 0.94 & 0.99 & 1.0 & 1.0 & 0.03 & 0.27 & 0.91 & 0.99 & 1.0 \\
\hline Pollen & $<0.01$ & $<0.01$ & $<0.01$ & $<0.01$ & $<0.01$ & $<0.01$ & 0.02 & 0.08 & 0.15 & 0.17 \\
\hline Feldspar & $<0.01$ & 0.12 & 0.74 & 1.0 & 1.0 & $<0.01$ & 0.10 & 0.37 & 0.93 & 1.0 \\
\hline Illite & $<0.01$ & 0.01 & 0.14 & 1.0 & 1.0 & $<0.01$ & 0.19 & 0.43 & 0.70 & 1.0 \\
\hline Kaolinite & $<0.01$ & $<0.01$ & $<0.01$ & 0.64 & 0.81 & $<0.01$ & $<0.01$ & 0.12 & 0.34 & 0.60 \\
\hline \multicolumn{11}{|c|}{$\mathrm{d} T=2 \mathrm{~K} T_{\text {fin }}=-29^{\circ} \mathrm{C}$} \\
\hline Bacteria & 0.26 & 0.86 & 0.99 & 1.0 & 1.0 & 0.13 & 0.43 & 0.86 & 0.99 & 1.0 \\
\hline Pollen & $<0.01$ & $<0.01$ & $<0.01$ & $<0.01$ & $<0.01$ & $<0.01$ & $<0.01$ & 0.02 & 0.13 & 0.33 \\
\hline Feldspar & $<0.01$ & 0.02 & 0.21 & 0.71 & 1.0 & 0.08 & 0.34 & 0.56 & 0.80 & 0.93 \\
\hline Illite & $<0.01$ & $<0.01$ & $<0.01$ & $<0.01$ & 0.02 & $<0.01$ & $<0.01$ & 0.04 & 0.24 & 0.47 \\
\hline Kaolinite & $<0.01$ & $<0.01$ & $<0.01$ & $<0.01$ & $<0.01$ & $<0.01$ & $<0.01$ & $<0.01$ & 0.02 & 0.15 \\
\hline \multicolumn{11}{|c|}{$\mathrm{d} T=1.5 \mathrm{~K} T_{\mathrm{fin}}=-24.5^{\circ} \mathrm{C}$} \\
\hline Bacteria & 0.11 & 0.61 & 0.96 & 1.0 & 1.0 & 0.05 & 0.25 & 0.69 & 0.97 & 1.0 \\
\hline Pollen & $<0.01$ & $<0.01$ & $<0.01$ & $<0.01$ & $<0.01$ & $<0.01$ & $<0.01$ & $<0.01$ & $<0.01$ & 0.03 \\
\hline Feldspar & $<0.01$ & $<0.01$ & $<0.01$ & 0.03 & 0.24 & $<0.01$ & $<0.01$ & 0.03 & 0.35 & 0.59 \\
\hline Illite & $<0.01$ & $<0.01$ & $<0.01$ & $<0.01$ & $<0.01$ & $<0.01$ & $<0.01$ & $<0.01$ & $<0.01$ & 0.01 \\
\hline Kaolinite & $<0.01$ & $<0.01$ & $<0.01$ & $<0.01$ & $<0.01$ & $<0.01$ & $<0.01$ & $<0.01$ & $<0.01$ & $<0.01$ \\
\hline
\end{tabular}

lar, but mixed-phase clouds were formed with pure minerals only but not with mixtures (Saharan and Asian dust) that are dominated by quartz (see Sect. 2.3.1).

Ervens et al. (2011), who investigated the impact of immersion and deposition freezing modes on ice formation in mixed-phase clouds, stated that immersion freezing formed less ice than deposition freezing because of lower onset temperatures in the immersion mode. However, this could not be confirmed in the present study. Newer laboratory measurements, which were used as basis of the parameterizations, showed in contrary higher initial temperatures in the immersion mode than in the deposition mode (see Tables 1 
Table 6. Ice water fractions from sensitivity studies with contact freezing. Liquid clouds: IWF $<0.1$, mixed-phase clouds: $0.1 \leq$ IWF $\leq 0.9$, and ice clouds: IWF $>0.9$. Cases referring to mixed-phase clouds and ice clouds are written in bold.

\begin{tabular}{|c|c|c|c|c|c|c|}
\hline \multicolumn{7}{|c|}{ Contact freezing } \\
\hline \multirow{2}{*}{$\begin{array}{l}\mathrm{AP} \\
F_{\mathrm{INP}}(\%)\end{array}$} & \multicolumn{3}{|c|}{ Regional haze } & \multicolumn{3}{|c|}{ Average continental } \\
\hline & 0.1 & 1 & 10 & 0.1 & 1 & 10 \\
\hline \multicolumn{7}{|c|}{$\mathrm{d} T=3 \mathrm{~K} T_{\text {fin }}=-40^{\circ} \mathrm{C}$} \\
\hline Bacteria & $<0.01$ & $<0.01$ & $<0.01$ & $<0.01$ & $<0.01$ & $<0.01$ \\
\hline Feldspar & $<0.01$ & $<0.01$ & $<0.01$ & $<0.01$ & $<0.01$ & 0.06 \\
\hline Montmorillonite & $<0.01$ & $<0.01$ & $<0.01$ & $<0.01$ & $<0.01$ & 0.04 \\
\hline Illite & $<0.01$ & $<0.01$ & $<0.01$ & $<0.01$ & $<0.01$ & $<0.01$ \\
\hline Kaolinite & $<0.01$ & $<0.01$ & $<0.01$ & $<0.01$ & $<0.01$ & $<0.01$ \\
\hline \multicolumn{7}{|c|}{$\mathrm{d} T=2 \mathrm{~K} T_{\text {fin }}=-29^{\circ} \mathrm{C}$} \\
\hline Bacteria & $<0.01$ & $<0.01$ & $<0.01$ & $<0.01$ & $<0.01$ & $<0.01$ \\
\hline Feldspar & $<0.01$ & $<0.01$ & $<0.01$ & $<0.01$ & $<0.01$ & 0.23 \\
\hline Montmorillonite & $<0.01$ & $<0.01$ & $<0.01$ & $<0.01$ & $<0.01$ & 0.12 \\
\hline Illite & $<0.01$ & $<0.01$ & $<0.01$ & $<0.01$ & $<0.01$ & $<0.01$ \\
\hline Kaolinite & $<0.01$ & $<0.01$ & $<0.01$ & $<0.01$ & $<0.01$ & $<0.01$ \\
\hline \multicolumn{7}{|c|}{$\mathrm{d} T=1.5 \mathrm{~K} T_{\text {fin }}=-24.5^{\circ} \mathrm{C}$} \\
\hline Bacteria & $<0.01$ & $<0.01$ & $<0.01$ & $<0.01$ & $<0.01$ & $<0.01$ \\
\hline Feldspar & $<0.01$ & $<0.01$ & $<0.01$ & $<0.01$ & $<0.01$ & 0.01 \\
\hline Montmorillonite & $<0.01$ & $<0.01$ & $<0.01$ & $<0.01$ & $<0.01$ & $<0.01$ \\
\hline Illite & $<0.01$ & $<0.01$ & $<0.01$ & $<0.01$ & $<0.01$ & $<0.01$ \\
\hline Kaolinite & $<0.01$ & $<0.01$ & $<0.01$ & $<0.01$ & $<0.01$ & $<0.01$ \\
\hline
\end{tabular}

and 4 with references therein) and, thus, immersion freezing produced more ice than deposition freezing. This agrees, on the other hand, with the findings of de Boer et al. (2011) and Lance et al. (2011) that liquid-dependent ice nucleation modes are dominant.

\subsubsection{Temperature difference $\Delta T$ and final temperature}

In all freezing modes, cases with the lowest temperature difference $(\Delta T=1.5 \mathrm{~K})$ and the corresponding highest final temperature of $-24.5^{\circ} \mathrm{C}$ showed hardly any ice formation. Exceptions are only cases with bacteria and feldspar in the immersion mode (Table 5). Contact ice formation did not occur with lower $\Delta T$ as the temperatures reached during the ascent of the air parcel were not low enough to give the more effective smaller particles the chance to act (Table 6). In the deposition mode, obviously temperatures below $-25^{\circ} \mathrm{C}$ are required to develop mixed-phase clouds (Table 7) as at higher temperatures the ice supersaturation is still too low. On the other hand, the largest $\Delta T$ of $3 \mathrm{~K}$ also hindered ice formation in contact and deposition modes, which might be affected by the presence of less interstitial particles.

\subsection{Comparison to measured INP numbers}

In this section there is a discussion on how realistic the assumed concentrations of INP are that lead to partial or complete cloud glaciation.

\subsubsection{Immersion freezing}

Regarding the cases of immersion freezing listed in Table 5, one has to look at the composition of cloud residuals that was investigated in several field campaigns. For example, Kamphus et al. (2010) measured $8 \%$ minerals in cloud droplet residuals and Hiranuma et al. (2013) found $3 \%$ mineral dust particles in cloud droplet residuals for all particle sizes and particle-size-resolved measurements indicated enhanced fractions for larger particles up to $17 \%$. In the model simulations mixed-phase clouds were formed already with potential INP fractions between 0.01 and $1 \%$. Thus, the dominant role of immersion freezing with mineral dust seems to be validated. It is confirmed by the fact that during INUIT field campaigns (Worringen et al., 2015; Schmidt et al., 2015) fractions of mineral dust up to $40 \%$ in ice residuals were observed. Similar numbers between 30 and $40 \%$ are reported by Kamphus et al. (2010) in ice particle residuals.

Bacteria need to be present as potential INP only as low as 0.001 to $0.01 \%$ to affect mixed-phase clouds, pollen with $1 \%$ potential INP. For pollen these numbers probably do not 
Table 7. Ice water fractions from sensitivity studies with deposition freezing. Liquid clouds: IWF $<0.1$, mixed-phase clouds: $0.1 \leq \mathrm{IWF} \leq 0.9$, and ice clouds: IWF $>0.9$. Cases referring to mixed-phase clouds and ice clouds are written in bold.

\begin{tabular}{|c|c|c|c|c|c|c|c|c|}
\hline \multicolumn{9}{|c|}{ Deposition freezing } \\
\hline \multirow{2}{*}{$\begin{array}{l}\text { AP } \\
F_{\text {INP }}(\%)\end{array}$} & \multicolumn{4}{|c|}{ Regional haze } & \multicolumn{4}{|c|}{ Average continental } \\
\hline & 0.01 & 0.1 & 1 & 10 & 0.01 & 0.1 & 1 & 10 \\
\hline \multicolumn{9}{|c|}{$\mathrm{d} T=3 \mathrm{~K} T_{\mathrm{fin}}=-40^{\circ} \mathrm{C}$} \\
\hline Bacteria & $<0.01$ & $<0.01$ & 0.05 & 0.52 & $<0.01$ & 0.02 & 0.14 & 0.42 \\
\hline Feldspar & $<0.01$ & $<0.01$ & $<0.01$ & $<0.01$ & $<0.01$ & 0.02 & 0.10 & 0.31 \\
\hline Illite 1 & $<0.01$ & $<0.01$ & $<0.01$ & $<0.01$ & $<0.01$ & $<0.01$ & 0.02 & 0.13 \\
\hline Illite 2 & $<0.01$ & $<0.01$ & $<0.01$ & $<0.01$ & $<0.01$ & $<0.01$ & 0.01 & 0.10 \\
\hline Saharan dust & $<0.01$ & $<0.01$ & $<0.01$ & $<0.01$ & $<0.01$ & $<0.01$ & $<0.01$ & 0.01 \\
\hline Asian dust & $<0.01$ & $<0.01$ & $<0.01$ & $<0.01$ & $<0.01$ & $<0.01$ & $<0.01$ & $<0.01$ \\
\hline \multicolumn{9}{|c|}{$\mathrm{d} T=2 \mathrm{~K} T_{\mathrm{fin}}=-29^{\circ} \mathrm{C}$} \\
\hline Bacteria & $<0.01$ & $<0.01$ & $<0.01$ & 0.06 & $<0.01$ & 0.04 & 0.27 & 0.51 \\
\hline Feldspar & $<0.01$ & $<0.01$ & $<0.01$ & $<0.01$ & $<0.01$ & $<0.01$ & 0.07 & 0.34 \\
\hline Illite 1 & $<0.01$ & $<0.01$ & $<0.01$ & $<0.01$ & $<0.01$ & $<0.01$ & 0.03 & 0.22 \\
\hline Illite 2 & $<0.01$ & $<0.01$ & $<0.01$ & $<0.01$ & $<0.01$ & $<0.01$ & 0.01 & 0.11 \\
\hline Saharan dust & $<0.01$ & $<0.01$ & $<0.01$ & $<0.01$ & $<0.01$ & $<0.01$ & $<0.01$ & 0.02 \\
\hline Asian dust & $<0.01$ & $<0.01$ & $<0.01$ & $<0.01$ & $<0.01$ & $<0.01$ & $<0.01$ & $<0.01$ \\
\hline \multicolumn{9}{|c|}{$\mathrm{d} T=1.5 \mathrm{~K} T_{\mathrm{fin}}=-24.5^{\circ} \mathrm{C}$} \\
\hline Bacteria & $<0.01$ & $<0.01$ & $<0.01$ & $<0.01$ & $<0.01$ & $<0.01$ & $<0.01$ & $<0.01$ \\
\hline Feldspar & $<0.01$ & $<0.01$ & $<0.01$ & $<0.01$ & $<0.01$ & $<0.01$ & $<0.01$ & $<0.01$ \\
\hline Illite 1 & $<0.01$ & $<0.01$ & $<0.01$ & $<0.01$ & $<0.01$ & $<0.01$ & $<0.01$ & $<0.01$ \\
\hline Illite 2 & $<0.01$ & $<0.01$ & $<0.01$ & $<0.01$ & $<0.01$ & $<0.01$ & $<0.01$ & $<0.01$ \\
\hline Saharan dust & $<0.01$ & $<0.01$ & $<0.01$ & $<0.01$ & $<0.01$ & $<0.01$ & $<0.01$ & $<0.01$ \\
\hline Asian dust & $<0.01$ & $<0.01$ & $<0.01$ & $<0.01$ & $<0.01$ & $<0.01$ & $<0.01$ & $<0.01$ \\
\hline
\end{tabular}

represent realistic cases; however, the pollen cases were anyway rather artificial as such large particles $(>10 \mu \mathrm{m})$ were actually not part of the aerosol particle spectrum. Bacteria concentrations in cloud water are given as average values of, e.g., $1.5 \times 10^{9} \mathrm{~m}^{-3}$ (Sattler et al., 2001), $2 \times 10^{10} \mathrm{~m}^{-3}$ (Bauer et al., 2002), and $7 \times 10^{4} \mathrm{~m}^{-3}$ (Amato et al., 2005; see also the review paper of Delort et al., 2010). Unfortunately, field measurements that give the number fractions of bacteria or primary biological aerosol particles (PBAP) related to the total concentrations of in-droplet particles are not available so far. An estimation was undertaken based on the results of Bauer et al. (2002). From field measurements in a continental background site, they determined the numbers of bacterial and fungi cells in cloud water and calculated the corresponding amount that would contribute to the amount of organic carbon (OC). For bacteria this contribution was estimated as $0.01 \%$. Analyses of cloud droplet residuals show, e.g., fractions of $3 \%$ (Twohy and Anderson, 2008) and $9 \%$ (Hiranuma et al., 2013) organic carbon. Based on these numbers, one could assume that 0.0003 to $0.0009 \%$ of the material contained in cloud drops consists of bacteria. This comes near the fraction of potential ice nucleating particles $F_{\text {INP }}$ of $0.001 \%$, which affects mixed-phase clouds via immersion freezing (see Table 5). Joly et al. (2014) investigated the ice nucleation efficiency of cloud water samples and distinguished total and biological INP. They estimated that - assuming that all biological INP were bacteria - in the temperature range between -8 and $-12{ }^{\circ} \mathrm{C} 0.6$ to $3.1 \%$ of the bacterial cells present in the cloud water samples could have acted as INP. Taking into account these values, a fraction $F_{\text {INP }}$ of $0.001 \%$ is probably still an overestimation of realistic bacterial ice nucleating particles in cloud drops.

Thus, one may conclude that the atmospheric immersion freezing with mineral dust particles will play a dominant role, while ice formation via immersion freezing of bacteria might take place in some extreme cases only.

\subsubsection{Contact and deposition freezing}

According to the cases listed in Tables 6 and 7, the formation of mixed-phase clouds via contact or deposition freezing requires that $10 \%$ of background aerosols consist of potential ice nucleating particles. Measurements during an INUIT field campaign on the high Alpine site Jungfraujoch (Schmidt et al., 2015) indicate a fraction of $1 \%$ minerals of the background aerosol; however, this value might be enhanced for continental situations in lower altitudes. A closer look was 
taken on the total number concentrations of ice nucleating particles acting as contact and deposition freezing particles during the model simulations. As shown in Fig. 9 for two different altitudes and corresponding temperatures, interstitial aerosol particles were always present during the ascent of the air parcel. Among these, only particles larger than $0.1 \mu \mathrm{m}$ in diameter were allowed to act as ice nucleating particles. The total number concentrations of those during the model simulations reached values up to $4 \times 10^{5} \mathrm{~m}^{-3}$ for the average continental and up to $2 \times 10^{6} \mathrm{~m}^{-3}$ for the regional haze distribution. Thus, fractions of potential ice nucleating particles $F_{\text {INP }}$ of $10 \%$ resulted in particle concentrations available for deposition and contact nucleation of at the most $4 \times 10^{4}$ and $2 \times 10^{5} \mathrm{~m}^{-3}$, respectively.

In Saharan dust events, Bangert et al. (2012) measured particle number concentrations up to $5 \times 10^{7} \mathrm{~m}^{-3}$. In Hande et al. (2015), simulated mineral dust number concentrations are $4 \times 10^{5} \mathrm{~m}^{-3}$ on average up to extreme values of $5.8 \times 10^{6} \mathrm{~m}^{-3}$. Thus, the numbers of potential INP used in the model simulations do not exceed realistic particle concentrations of mineral dust.

Near-surface concentrations of bacteria range between $1 \times 10^{3}$ and $5 \times 10^{5} \mathrm{~m}^{-3}$ depending on ecotypes (Burrows et al., 2009), but these values are certainly not reached in upper cloud regions. On the other hand, DeLeon-Rodriguez et al. (2013) reported from field measurements in lowand high-altitude air masses that bacterial cells represented nearly $20 \%$ of the total particles in the diameter range between 0.25 and $1 \mu \mathrm{m}$. This is approximately the size range of potential ice nucleating particles in the present model simulations. For even larger particles in the coarse-mode high fractions of PBAP (primary biological particles) are also reported by Manninen et al. (2014). However, the numbers of potential INP used in the model simulations probably overestimate real bacteria concentrations.

Considering these factors one may conclude that the conditions for atmospheric deposition and contact freezing could be sufficient in some cases to form mixed-phase clouds from primary ice formation by mineral dust particles. In some extreme cases, the formation of mixed-phase clouds might be possible via deposition nucleation on bacteria. On the other hand, the initial particle spectra used for the present model simulations contain small amounts of particles larger than $1 \mu \mathrm{m}$ (see Fig. 8), which would be able to act as contact ice nucleating particles much more efficiently (see Sect. 2.2.1). Thus, in cases where larger INP are present in or around atmospheric clouds contact freezing might be significantly enhanced.

\subsection{Ice particle spectra, single and coupled freezing processes}

In this section only simulations with the most efficient ice formation are treated, i.e., using the average continental particle distribution and a medium $\Delta T=2 \mathrm{~K}$ leading to final temperatures of $-29^{\circ} \mathrm{C}$. The potential fractions $F_{\text {INP }}$ were set to $10 \%$ for feldspar, illite, montmorillonite, and kaolinite. Bacteria and pollen were not considered here as those high values of $F_{\mathrm{INP}}$ are not realistic (see discussion in Sect. 4.2). Figure 10 shows the ice particle number size distributions at different altitudes and corresponding temperatures for single deposition, contact, and immersion freezing processes that are discussed in the next paragraphs.

The ice particle spectra affected by immersion freezing are rather narrow starting with a particle diameter of $1 \mu \mathrm{m}$ due to the smallest drop size. However, larger drops around $30 \mu \mathrm{m}$ in diameter were frozen first as their content of insoluble particles is higher. With decreasing temperature, also smaller drops can freeze while ice particles grow by the deposition of water vapor and by riming; i.e., the ice particle spectra broaden in both directions. Finally, they are still smaller than the ones formed by deposition freezing. The differences between the dust types are much more evident than in the other modes and the final ice particle numbers are higher, in particular for feldspar.

In the contact mode, the simulated ice particle spectrum is even somewhat narrower. At temperatures around $-20^{\circ} \mathrm{C}$, the maximum of the drop number concentration lies at $30 \mu \mathrm{m}$. This indicates that large supercooled drops froze by collisions with larger particles as in this temperature range smaller particles are hardly efficient as contact INP. Lowering the temperature down to $-29^{\circ} \mathrm{C}$ extends the ice particle spectra towards larger sizes; i.e., the ice particles grow by the deposition of water vapor and by riming but still only small amounts of small drops are freezing. Thus, contact freezing is strongly controlled by the collision kernel. The number concentrations of ice particles formed on feldspar and montmorillonite are rather similar at $-30^{\circ} \mathrm{C}$ but strongly different at $-21^{\circ} \mathrm{C}$. This is due to the fact that smaller feldspar particles are active at higher temperatures as smaller montmorillonite particles (see Fig. 4).

The ice particle spectra due to deposition freezing start with small sizes and develop towards larger sizes during the ascent of the cloud. This indicates that first, as primary ice formation, small ice particles are formed due to the sizes of the involved particles $(0.1 \mu \mathrm{m}$ at least up to $3 \mu \mathrm{m}$ maximum, see the initial particle spectra in Fig. 8). Afterwards, these pristine ice particles serve as nuclei for secondary ice formation, i.e., by collisions with supercooled liquid drops; this process produces ice particles of larger sizes; see maximum around $40 \mu \mathrm{m}$ in Fig. 10. Furthermore, all ice particles grow by the deposition of water vapor and by riming leading to ice particles larger than $100 \mu \mathrm{m}$. Thus, a broad spectrum of ice particles evolved from deposition freezing. The number concentrations vary by 1 order of magnitude from illite 2 to feldspar. The oscillations of the spectra on the left hand side are an artifact effect of the size classes of the particles acting as INP starting with $0.1 \mu \mathrm{m}$ diameter; they vanish if the lower size of the INP is limited by the critical radius only (Eq. 16). 

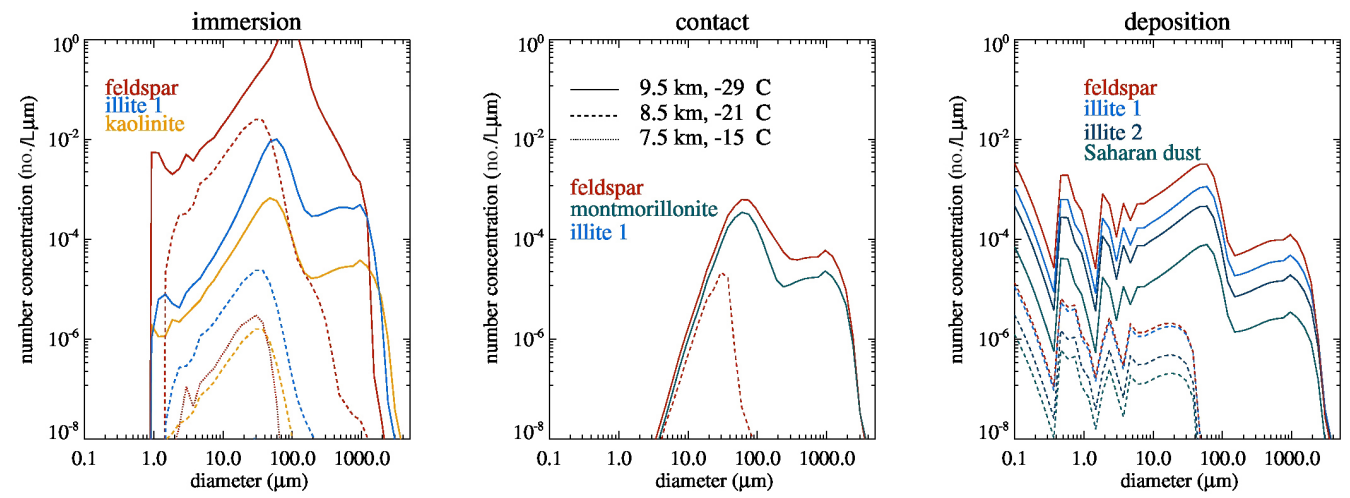

Figure 10. Development of ice particle numbers with altitude and corresponding temperature, marked by different line styles, for deposition, contact and immersion freezing. Types of INP marked by colors. Model simulations with average continental number size distribution and with $\Delta T=2 \mathrm{~K}$. Number concentrations per $\mathrm{L}$ and $\mu \mathrm{m}$ as a function of particle diameter.

Coupled cases were simulated to investigate the competition between contact and immersion modes as both freeze supercooled drops, and the competition between contact and deposition freezing as both interact with inactivated particles. The following combinations were studied: (1) feldspar and (2) illite 1 as for these particle types parameterizations for all freezing modes are available based on INUIT measurements. Additionally, some mixed cases were investigated, i.e., one INP type for one freezing mode, another INP type for the other freezing mode; these were for coupled contact and immersion freezing: (3) montmorillonite + kaolinite and (4) feldspar + kaolinite. These cases were selected to combine weaker immersion freezing INP (kaolinite) with stronger contact freezing INP (feldspar and montmorillonite); see Fig. 12a. For coupled deposition and contact freezing the mixed cases were (3) illite $2+$ montmorillonite and (4) Saharan dust + feldspar. As can be noted from Tables 5 to 7 , the ice water fractions evolved from feldspar INP are similar for deposition and contact freezing but significantly higher for immersion freezing. The effects from illite 1 INP differ between the freezing modes (immersion highest, contact lowest). The combination illite $2+$ montmorillonite in deposition and contact modes was selected because the resulted ice water fractions were similar, which is also the case for the combination montmorillonite + kaolinite in contact and immersion modes.

In contrast, the fourth combinations Saharan dust + feldspar (deposition and contact) and feldspar + kaolinite (contact and immersion) were chosen as the ice water fractions evolved by contact freezing were higher. Figure 11 shows the ice particle number size distributions at different altitudes and corresponding temperatures for coupled deposition and contact, and coupled contact and immersion freezing processes.

One can note from Fig. 11 that deposition and contact freezing are hardly in competition. The narrow ice particle spectrum due to contact freezing alone is enhanced towards smaller sizes due to deposition freezing. Small ice particles are formed by deposition freezing due to the sizes of the involved particles ( 0.1 to $3 \mu \mathrm{m})$, large ice particles are formed by contact freezing due to the sizes of involved liquid drops (30 to $50 \mu \mathrm{m}$, see Fig. 10). When the first ice formation is observed via contact and deposition freezing at temperatures around $-20^{\circ} \mathrm{C}$, in the contact mode only dust particles larger than $0.4 \mu \mathrm{m}$ (feldspar), $0.8 \mu \mathrm{m}$ (illite), and $1 \mu \mathrm{m}$ (kaolinite) are active (see Fig. 4); thus, all smaller particles and fractions of the larger particles are available for deposition freezing. Even at lower temperatures, still small particles remain for deposition freezing as these are less efficient to collide with drops. The common ice particle spectra of coupled deposition and contact freezing are as broad as the ones from single deposition freezing, but the number concentrations in the larger size range are enhanced in cases with efficient contact freezing, i.e., with feldspar and montmorillonite INP.

Regarding coupled contact and immersion freezing, here the latter is the dominant process. Using the same particle types there is no effect visible from contact freezing (feldspar, illite1). However, in cases where the contact INP are more efficient than the immersion INP (feldspar or montmorillonite in contrast to kaolinite) the number concentrations are slightly enhanced in the size range larger than $90 \mu \mathrm{m}$ (see Figs. 10 and 11).

The total numbers of liquid drops and ice particles in $\mathrm{cm}^{-3}$ as a function of temperature are given in Fig. 12. Results from single freezing processes are shown in Fig. 12a. In the upper part of the figure, liquid drop numbers are shown as solid lines. The black line represents liquid drop numbers on the order of $8 \times 10^{2} \mathrm{~cm}^{-3}$, which applies for all cases except immersion freezing with feldspar. Below, in all remaining plot lines ice particle numbers are given in Fig. 12a for the three single freezing processes as colored lines (the colors describe the types of INP) with different line styles: solid lines for immersion freezing (feldspar, illite1, and kaolinite), dotted lines for contact freezing (feldspar, montmorillonite, 

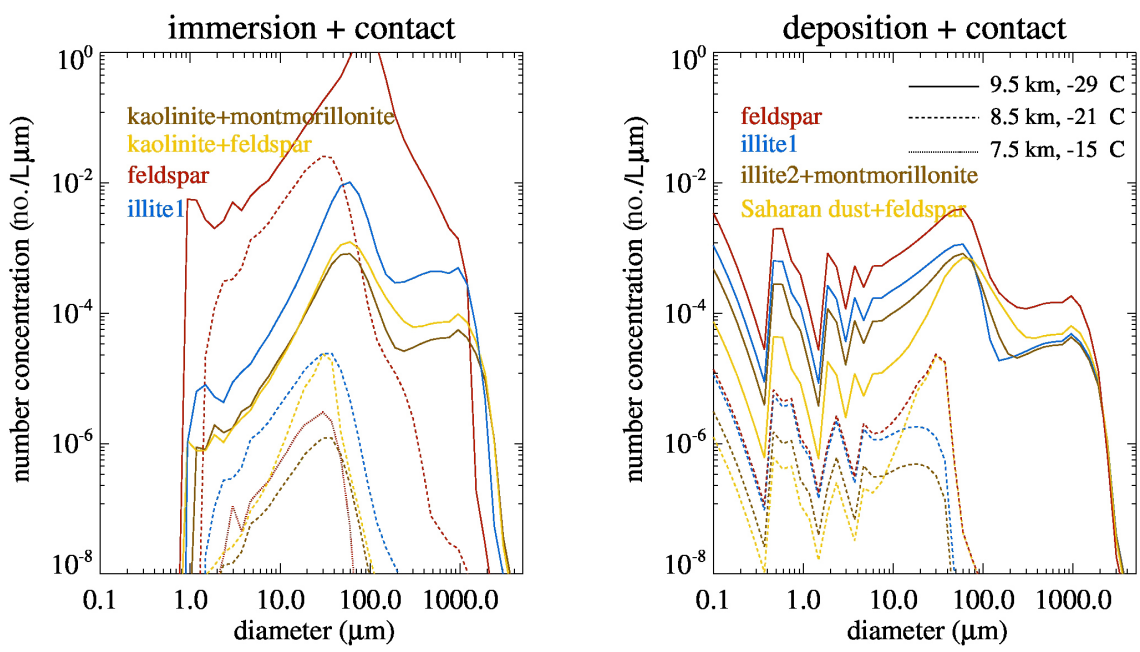

Figure 11. Development of ice particle numbers with altitude and corresponding temperature, marked by different line styles, for coupled freezing processes. Types of INP marked by colors. Model simulations with average continental number size distribution, and with $\Delta T=2 \mathrm{~K}$. Number concentrations per $\mathrm{L}$ and $\mu \mathrm{m}$ as a function of particle diameter.
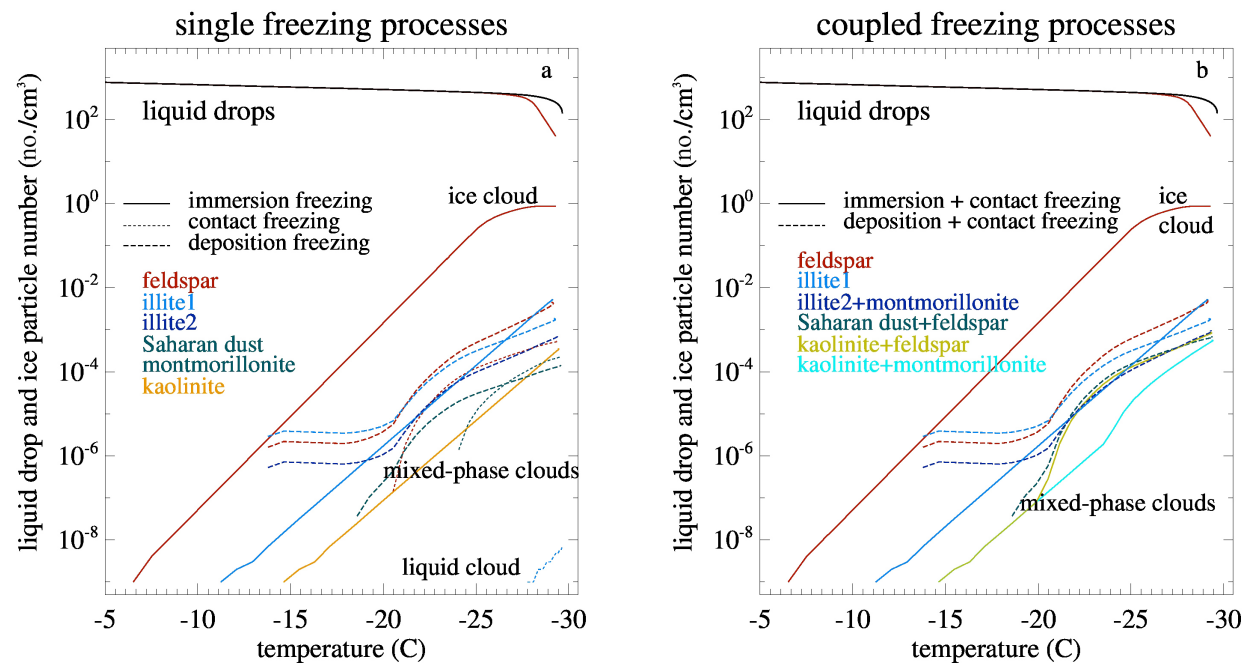

Figure 12. Total numbers of liquid drops and ice particles as a function of temperature for single and coupled freezing processes that are marked by different line styles. Types of INP marked by colors. Model simulations with average continental number size distribution and with $\Delta T=2 \mathrm{~K}$. Numbers concentrations per $\mathrm{cm}^{3}$ as a function of temperature.

and illite), and broken lines for deposition freezing (feldspar, illite1, illite2, and Saharan dust).

From the ice particle numbers at the lowest temperature of $-29^{\circ} \mathrm{C}$, one can clearly distinguish between cloud types: ice particle numbers around $1 \mathrm{~cm}^{-3}$ represent an ice cloud (immersion freezing with feldspar), ice particle numbers around $1 \times 10^{-8} \mathrm{~cm}^{-3}$ represent a liquid cloud (i.e., the ice water fraction is smaller than 0.1 ; contact freezing with illite), and ice particle numbers between $1 \times 10^{-4} \mathrm{~cm}^{-3}$ and $1 \times 10^{-2} \mathrm{~cm}^{-3}$ represent mixed-phase clouds (all other cases). In the only case of ice cloud formation (immersion with feldspar), the liquid drop number is affected as well: it is reduced to $5 \times 10^{1} \mathrm{~cm}^{-3}$ (i.e., the ice water fraction is larger than 0.9); see red solid line in the upper part of the figure.

It can be seen that the development of ice particle numbers with decreasing temperature via immersion freezing (colored solid lines) is similar to the development of the numbers of active sites immersed in the drops with decreasing temperature (shown in Fig. 1). In contrast, contact freezing (dotted lines) is not ruled by the temperature alone but also by the collision efficiencies between potential INP and supercooled drops (see Sect. 2.2), while deposition freezing (broken lines) is ruled by the ice supersaturation (see Sect. 2.3), which, of course, increases with decreasing temperature. 
Comparing the liquid drop numbers to the ice particle numbers, one notes that the differences are approximately between 4 and 6 orders of magnitude in cases of mixedphase clouds and still more than 1 order of magnitude in the case of the ice cloud. This indicates that the glaciation of the clouds proceeds mainly by the growth of ice particles at the expense of liquid drops (Bergeron-Findeisen process or riming). Here, some effects are presumably overestimated as from the air parcel no cloud particle sedimentation is possible.

Figure $12 \mathrm{~b}$ shows results for the coupled freezing processes. Again liquid drop numbers are given as solid lines in the upper part of the figure. The black line represents liquid drop numbers, which applies for all cases except immersion + contact freezing with feldspar. Lower plot lines in Fig. 12b show ice particle numbers for the two coupled freezing processes as colored lines (the colors describe the types of INP) with different line styles: solid lines for immersion + contact freezing (feldspar, illite1, kaolinite + feldspar, kaolinite + montmorillonite), and broken lines for deposition + contact freezing (feldspar, illite1, illite $2+$ montmorillonite, Saharan dust + feldspar).

Ice clouds and mixed-phase clouds differ in the ice particle numbers at the lowest temperature of $-29^{\circ} \mathrm{C}$ : ice particle numbers around $1 \mathrm{~cm}^{-3}$ represent an ice cloud (immersion + contact freezing with feldspar), and ice particle numbers between $5 \times 10^{-4}$ and $1 \times 10^{-2} \mathrm{~cm}^{-3}$ represent mixed-phase clouds (all other cases). In the only case of ice cloud formation the liquid drop number is affected as well; see red solid line in the upper part of the figure.

It is obvious that in those cases where one process is inferior the ice particle numbers are completely determined by the dominant process. This is the case in coupled immersion and contact freezing with feldspar and illite 1 but not with kaolinite + feldspar and kaolinite + montmorillonite, where the effects of contact freezing are visible at lower temperatures $\left(<-20^{\circ} \mathrm{C}\right)$. Coupled deposition and contact freezing shows the same results as for deposition freezing alone in the case of illite. In the other cases, feldspar, illite $2+$ montmorillonite, and Saharan dust + feldspar, there are at least some small enhancements visible at temperatures lower than $-20{ }^{\circ} \mathrm{C}$ when contact freezing becomes more efficient.

\subsection{Comparison of presently simulated ice particle numbers to previous literature data}

In this section results from the model simulations are compared to data from previous model simulations and atmospheric measurements. As comparison parameter the number of ice particles formed at the end of the air parcel ascent was used as shown in Fig. 12. These simulations were performed with the continental particle distribution, $\mathrm{d} T=2 \mathrm{~K}$, and $F_{\mathrm{INP}}=10 \%$; i.e., for $F_{\mathrm{INP}}$ values lower than $10 \%$ less ice particle numbers are formed.
Eidhammer et al. (2009) used an air parcel model to perform intercomparisons of three heterogeneous ice nucleation parameterizations, which linked aerosol types and numbers to ice particle number concentrations. One of these was the previous immersion freezing parameterization of Diehl and Wurzler (2004) that has been replaced by a new one in this study. This description was related to the volume of liquid similar as the well-known Bigg parameterization (Bigg, 1953). The criticisms was that some constraints are required that limit the number of potential ice nucleating particles. The present parameterization is related to the insoluble particle mass contained in the drops and the constraint is given by the factor $F_{\text {INP }}$ in Eq. (8). Ice particle numbers found by Eidhammer et al. (2009) with the Diehl and Wurzler (2004) description were in the range of $5 \times 10^{-2}$ to $5 \times 10^{-1} \mathrm{~cm}^{-3}$, while results from the current simulations are on the order of $1 \times 10^{-3} \mathrm{~cm}^{-3}$ for mixed-phase clouds (see Fig. 12; immersion freezing).

In Ervens and Feingold (2012), the effects of five ice nucleation schemes for immersion freezing with particles showing surface characteristics like kaolinite particles on the properties of mixed-phase clouds were compared in air parcel studies. The present parameterization of immersion freezing is similar to the so-called deterministic scheme of Ervens and Feingold (2012), which includes a cumulative activation spectrum as a function of temperature. Using this scheme in their parcel model with polydisperse INP, they found ice particle numbers from $2 \times 10^{-4}$ to $1 \times 10^{-3} \mathrm{~cm}^{-3}$. In spite of differences between the present and previous air parcel studies (e.g., height of parcel elevation) the present results of immersion freezing with kaolinite particles, i.e., $3.5 \times 10^{-4} \mathrm{~cm}^{-3}$ (see Fig. 12a), agree very well.

Fan et al. (2010) simulated two deep convective clouds from field campaigns, one cloud formed under clean conditions, the other under polluted conditions with biomass burning. They used a three-dimensional cloud-resolving model with different immersion-condensation-deposition and homogeneous ice nucleation parameterizations. The averaged cloud properties for their clean case showed ice particle numbers between $1.3 \times 10^{-2}$ and $1.5 \times 10^{-2} \mathrm{~cm}^{-3}$, depending on the ice nucleation schemes. For the comparison coupled immersion and deposition freezing were simulated with kaolinite acting in the immersion mode, Saharan dust in the deposition mode (not shown in Fig. 12b). These two particle types might represent the behavior of "mean" atmospheric INP. During the calculations d $T$ was varied by 2 , 2.5 , and $3 \mathrm{~K}$. The final ice particle numbers were $4.8 \times 10^{-4}$, $2.2 \times 10^{-2}$, and $6.4 \times 10^{-1} \mathrm{~cm}^{-3}$, respectively, and, thus, best agreement with a deep convective cloud was obtained with $\mathrm{d} T=2.5 \mathrm{~K}$.

Kulkarni et al. (2012) used Arizona test dust (ATD) and kaolinite to experimentally investigate and model deposition freezing. However, their measured activated fractions of particles as a function of ice supersaturation were at least 1 to 2 orders of magnitude larger than the ones used as basis for 
the parameterizations in the present study. Therefore, not surprisingly, the modeled ice particle numbers found by Kulkarni et al. (2012) were between $2 \times 10^{-3}$ and $1 \times 10^{-2} \mathrm{~cm}^{-3}$ and up to 2 orders of magnitude larger than the ones found in the present simulations $\left(1.4 \times 10^{-4} \mathrm{~cm}^{-3}\right.$ for Saharan dust, $7.2 \times 10^{-4} \mathrm{~cm}^{-3}$ for illite2, $1.8 \times 10^{-3} \mathrm{~cm}^{-3}$ for illite1, and $4.5 \times 10^{-3} \mathrm{~cm}^{-3}$ for feldspar; see Fig. 12a).

Observations of atmospheric clouds reported ice particle number concentrations of $1 \times 10^{-4}$ to $10 \mathrm{~cm}^{-3}$ in convective clouds (Hobbs et al., 1980), $1 \times 10^{-5}$ to $5 \times 10^{-2} \mathrm{~cm}^{-3}$ in mixed-phase clouds (McFarquhar et al., 2007; modeled by Fridlind et al., 2007), and $1 \times 10^{-1}$ to $1 \mathrm{~cm}^{-3}$ in ice clouds (Krämer et al., 2009). Thus, the ice particle numbers formed during the present model simulations; i.e., $1 \times 10^{-4}$ to $1 \times 10^{-2} \mathrm{~cm}^{-3}$ for mixed-phase clouds and $9 \times 10^{-1} \mathrm{~cm}^{-3}$ for ice clouds (see Fig. 12), represent the status of real atmospheric clouds.

\section{Summary and conclusions}

In this paper improvements and modifications of the spectralbin microphysics embedded in an adiabatic air parcel model with entrainment as described in Diehl et al. (2006) are presented. They include (1) a particle-type-dependent parameterization of immersion freezing, (2) a particle-type and size-resolved parameterization of contact freezing, and (3) a particle-type-dependent description of deposition freezing. Sensitivity studies with the modified version of the microphysics package demonstrated the impact of ice nuclei concentrations and types on ice formation in convective mixedphase clouds. Single and coupled freezing processes were studied and the following parameters were varied: initial aerosol particle number size distributions, final temperature, types of INP, and the fractions of potential INP.

The majority of mixed-phase and ice clouds were formed at temperatures below $-25^{\circ} \mathrm{C}$, with the average continental particle number size distribution and with immersion freezing, even with smaller values of $F_{\text {INP }}$ (fractions of potential INP).

First, larger drops freeze in the immersion mode because they contain more particulate material. During the updraft of the cloud and corresponding lower temperatures, the ice particle spectra develop towards smaller sizes. Contact freezing is limited by the collision kernel between supercooled drops and potential ice nucleating particles. Large particles collide more often with large drops. Because they are more efficient con-tact INP than smaller particles this leads at first to the formation of larger ice particles.. Smaller particles that represent in general the majority of the particle spectrum become effective at lower temperatures and, thus, contact freezing becomes relevant below $-25^{\circ} \mathrm{C}$. During coupled immersion and contact freezing immersion freezing is the dominant process in cases with the same INP types (feldspar, illite). In mixed cases where contact INP are more efficient than immersion INP (feldspar or montmorillonite with kaolinite), contact freezing contributes similarly as immersion freezing to ice formation. In such cases sufficient liquid drops are available for contact freezing.

The importance of deposition freezing lies in secondary ice formation: at first, small pristine ice particles are formed due to the sizes of the involved particles, which trigger the freezing of supercooled drops by collisions. Thus, a broader ice particle spectrum is generated than by immersion and contact freezing. Regarding coupled contact and deposition freezing, there is hardly competition because both start moderately at higher temperatures so that inactivated particles are present for both freezing modes.

The most effective ice nucleating particles are bacteria, feldspar, and illite; on the contrary, of minor importance are pollen, montmorillonite, and kaolinite. Ice formation by immersion freezing is very sensitive to the different mineral dust types leading to ice particle numbers varying by 3 orders of magnitude.

From the model results it can be concluded that the formation of mixed-phase and ice clouds in convective situations is promoted by (1) the immersion freezing mode; (2) broad drop size spectra containing small as well as large drops; (3) insoluble particles composed by bacteria, feldspar, and illite; and (4) temperatures below $-25^{\circ} \mathrm{C}$.

The dominance of the immersion mode confirms the findings of de Boer et al. (2011) and Lance et al. (2011) about the importance of liquid-dependent ice nucleation modes. The role of contact freezing remained still unclear. In Diehl et al. (2006) it was estimated to be the most efficient process; however, this was because of assuming high freezing efficiencies for all particle sizes. Thus, the effects in the present model simulations with the modified contact freezing description should be closer to the real situation in the atmosphere. Contact freezing might be enhanced in atmospheric situations where particles larger than $1 \mu \mathrm{m}$ are present in higher amounts. The dependence of ice formation on the properties of the liquid drop size spectrum was also observed by Lance et al. (2011). This should be investigated in more detail but was not the main focus of the present simulations, which concentrated more on the impact of ice nucleating particle types.

Bacteria as primary biological particles were found to affect mixed-phase clouds or even ice clouds; however, the critical factor is the availability in atmospheric environment and clouds. Together with estimations of their atmospheric occurrence the present model simulations indicate that they are probably not involved in significant ice formation. This has been suggested already by Phillips et al. (2009), Diehl and Wurzler (2010), and Paukert and Hoose (2014). Thus, mineral dust particles seem to be the most important INP. The model results indicate that ice formation by immersion freezing is similarly sensitive to the mineral dust types as to the potential fractions of INP. Therefore, the composition of dust particles decides their impact on ice nucleation in clouds; es- 
sential components are feldspar and illite. In particular, the investigation of typical atmospheric mixtures of mineral dust is relevant.

The microphysical package presented here was included into an air parcel model, which has the advantage that all changes in the microphysical evolution of the cloud can be attributed to microphysical processes. On the other hand, some compromises are required concerning the cloud dynamics including some well-known weaknesses as precipitation-sized cloud particles do not sediment but stay inside the parcel. As they are not removed from the parcel they could grow to unrealistic sizes. This can happen notably in the ice phase and lead to an overestimation of cloud glaciation. Some more limitations that should be considered are related to immersion and contact freezing. During the cloud model runs each drop contains insoluble material serving as immersion ice nucleus because the particles in the model are internally mixed. In a real cloud there might be drops that do not contain any potential ice nucleating material. Furthermore, the values of $F_{\text {INP }}$ used in the model represent maximum estimations as not all dust particles are able to affect freezing at atmospheric temperatures. For contact freezing, the amount of interstitial inactivated particles is limited in an air parcel model while in a real cloud there might be more inactivated particles at the edges or beneath the cloud.

The further goal is to implement the new microphysical scheme into to a more complex state-of-the-art model system. For this purpose presently the three-dimensional cloud model COSMO-SPECS (Grützun et al., 2008) has been employed. This model contains the microphysical scheme as used in Diehl et al. (2006) within the adiabatic parcel model, which is replaced by the microphysical scheme presented here. Such an improvement will allow for more complex model simulations including the formation of precipitation, which will elucidate the role of ice nucleating particles in atmospheric clouds.

Acknowledgements. This work is part of the research group INUIT (Ice Nuclei research UnIT) FOR1525 and was supported by the Deutsche Forschungsgemeinschaft under grant DI 1539/1-1. We appreciate the INUIT laboratory and field groups for providing their experimental data as basis of parameterizations and for helpful discussions. Thanks to Karin Ardon-Dryer for providing unpublished material. We would like to thank Corinna Hoose for fruitful discussions and helpful comments and suggestions.

Edited by: B. Ervens

\section{References}

Amato, P., Ménager, M., Sancelme, M., Laj, P., Mailhot, G., and Delort, A.-M.: Microbial population in cloud water at the Puy de Dôme: implications for the chemistry of clouds, Atmos. Environ. 39, 4143-4153, 2005.
Ansmann, A., Althausen, D., Müller, D., Seifert, P., Freudenthaler, V., Heese, B., Wiegner, M., Pisani, G., Knippertz, P., and Dubovik, O.: Influence of Saharan dust on cloud glaciation in southern Morocco during Saharan mineral dust experiment, J. Geophys. Res., 113, D04210, doi:10.1029/2007JD008785, 2008.

Atkinson, J. D., Murray, B. J., Woodhouse, M. T., Whale, T. F., Baustian, K. J., Carslaw, K. S., Dobbie, S., O'Sullivan, D., and Malkin, T. L.: The importance of feldspar for ice nucleation by mineral dust in mixed-phase clouds, Nature, 498, 355-358, doi:10.1038/nature12278, 2013.

Bangert, M., Nenes, A., Vogel, B., Vogel, H., Barahona, D., Karydis, V. A., Kumar, P., Kottmeier, C., and Blahak, U.: Saharan dust event impacts on cloud formation and radiation over Western Europe, Atmos. Chem. Phys., 12, 4045-4063, doi:10.5194/acp-124045-2012, 2012.

Bauer, H., Kasper-Giebl, A., Löflund, M., Giebl, H., Hitzenberger, R., Zibuschka, F., and Puxbaum, H.: The contribution of bacteria and fungal spores to the organics content of cloud water, precipitation and aerosols, Atmos. Res., 64, 109-119, 2002.

Bigg, E. K.: The formation of atmospheric ice crystals by the freezing of droplets, Q. J. Roy. Meteorol. Soc., 79, 510-519, 1953.

Broadley, S. L., Murray, B. J., Herbert, R. J., Atkinson, J. D., Dobbie, S., Malkin, T. L., Condliffe, E., and Neve, L.: Immersion mode heterogeneous ice nucleation by an illite rich powder representative of atmospheric mineral dust, Atmos. Chem. Phys., 12, 287-307, doi:10.5194/acp-12-287-2012, 2012.

Burrows, S. M., Elbert, W., Lawrence, M. G., and Pöschl, U.: Bacteria in the global atmosphere - Part 1: Review and synthesis of literature data for different ecosystems, Atmos. Chem. Phys., 9, 9263-9280, doi:10.5194/acp-9-9263-2009, 2009.

Busch, B., Kandler, K., Schütz, L., and Neusüß, C.: Hygroscopic properties and water soluble volume fraction of atmospheric particles in the diameter range from $50 \mathrm{~nm}$ to $3.8 \mu \mathrm{m}$ during LACE 98, J. Geophys. Res., 107 D, LAC 2-1-LAC 2-11, 2002.

Connolly, P. J., Möhler, O., Field, P. R., Saathoff, H., Burgess, R., Choularton, T., and Gallagher, M.: Studies of heterogeneous freezing by three different desert dust samples, Atmos. Chem. Phys., 9, 2805-2824, doi:10.5194/acp-9-2805-2009, 2009.

de Boer, G., Morrison, H., Shupe, M. D., and Hildner, R.: Evidence of liquid dependent ice nucleation in high-latitude stratiform clouds from surface remote sensors. Geophys. Res. Lett., 38, L01803, doi:10.1029/2010GL046016, 2011.

DeLeon-Rodriguez, N., Lathem, T. L., Rodriguez-R, L. M., Barazesh, J. M., Anderson, B. E., Beyersdorf, A. J., Ziemba, L. D., Bergin, M., Nenes, A., and Konstantinidis, K. T.: Microbiome of the upper troposphere: Species composition and prevalence, effects of tropical storms, and atmospheric implications, P. Natl. Acad. Sci., 110, 2575-2580, doi:10.1073/pnas.1212089110, 2013.

Delort, A.-M., Vaïtilingom, M., Amato, P., Sancelme, M., Parazols, M., Mailhot, G., Laj, P., and Deguillaume, L.: A short overview of the microbial population in clouds: Potential roles in atmospheric chemistry and nucleation processes, Atmos. Res., 98, 249-260, 2010.

DeMott, P. J., Prenni, A. J., McMeeking, G. R., Sullivan, R. C., Petters, M. D., Tobo, Y., Niemand, M., Möhler, O., Snider, J. R., Wang, Z., and Kreidenweis, S. M.: Integrating laboratory and field data to quantify the immersion freezing ice nucleation activ- 
ity of mineral dust particles, Atmos. Chem. Phys., 15, 393-409, doi:10.5194/acp-15-393-2015, 2015.

Diehl, K. and Wurzler, S.: Heterogeneous drop freezing in the immersion mode: Model calculations considering soluble and insoluble particles in the drops, J. Atmos. Sci., 61, 2063-2072, 2004.

Diehl, K. and Wurzler, S.: Air parcel model simulations of a convective cloud: Bacteria acting as immersion ice nuclei, Atmos. Environ., 44, 4622-4628, 2010.

Diehl, K., Matthias-Maser, S., Mitra, S. K., and Jaenicke, R.: The ice nucleating ability of pollen. Part II: Laboratory studies in immersion and contact freezing modes, Atmos. Res., 61, 125-133, 2002.

Diehl, K., Simmel, M., and Wurzler, S.: Numerical simulations of the impact of aerosol properties and drop freezing modes on the glaciation, microphysics, and dynamics of clouds, J. Geophys. Res., 111, D07202, doi:10.1029/2005JD005884, 2006.

Diehl, K., Simmel, M., and Wurzler, S.: Effects of drop freezing on microphysics of an ascending cloud parcel under biomass burning conditions, Atmos. Environ., 41, 303-314, 2007.

Diehl, K., Schmithüsen, H., Debertshäuser, M., Borrmann, S., and Mitra, S. K.: Laboratory investigations of contact and immersion freezing of mineral dust using an acoustic levitator, Proceedings European Aerosol Conference, Granada, Spain, 2012.

Eidhammer, T., DeMott, P. J., and Kreidenweis, S. M.: A comparison of heterogeneous ice nucleation parameterizations using a parcel model framework. J. Geophys. Res., 114, D06202, doi:10.1029/2008JD011095, 2009.

Ekman, A. M. L., Engström, A., and Wang, C.: The effect of aerosol composition and concentration on the development and anvil properties of a continental deep convective cloud, Q. J. Roy. Meteorol. Soc., 133, 1439-1452, 2007.

Ervens, B. and Feingold, G.: On the representation of immersion and condensation freezing in cloud models using different nucleation schemes, Atmos. Chem. Phys., 12, 5807-5826, doi:10.5194/acp-12-5807-2012, 2012.

Ervens, B. and Feingold, G.: Sensitivities of immersion freezing: Reconciling classical nucleation theory and deterministic expressions, J. Geophys. Res. Lett., 40, 3320-3324, doi:10.1002/grl.50580, 2013.

Ervens, B., Feingold, G., Sulia, K., and Harrington, J.: The impact of microphysical parameters, ice nucleation mode, and habit growth on the ice/liquid partitioning in mixed-phase Arctic clouds, J. Geophys. Res., 116, D17205, doi:10.1029/2011JD015729, 2011.

Fan, J., Comstock, J. M., Ovchinnikov, M., McFarlane, S. A., McFarquhar, G., and Allen, G.: Tropical anvil characteristics and water vapour of the tropical tropopause layer: Impact of heterogeneous and homogeneous freezing parameterizations, J. Geopys. Res., 115, D12201, doi:10.1029/2009JD012696, 2010.

Fridlind, A. M., Ackerman, A. S., McFarquhar, G., Zhang, G., Poellot, M. R., DeMott, P. J., Prenni, A. J., and Heymsfield, A. J.: Ice properties of single-layer stratocumulus during the MixedPhase Arctic Cloud Experiment: 2. Model results, J. Geophys. Res., 112, D24202, doi:10.1029/2007JD008646, 2007.

Gilmore, M. S., Straka, J. M., and Rasmussen, E. N.: Precipitation and Evolution Sensitivity in Simulated Deep Convective Storms: Comparisons between liquid-only and simple ice and liquid phase microphysics, Mon. Weather Rev., 132, 1897-1916, 2004.
Gorbunov, B., Baklanov, A., Kakutkina, N., Windsor, H. L., and Toumi, R.: Ice nucleation on soot particles, J. Aerosol Sci., 32, 199-215, 2001.

Grützun, V., Knoth, O., and Simmel, M.: Simulation of the influence of aerosol particle characteristics on clouds and precipitation with LM-SPECS: Model description and first results, Atmos. Res., 90, 233-242, 2008.

Hande, L. B., Engler, C., Hoose, C., and Tegen, I.: Seasonal variability of Saharan desert dust and ice nucleating particles over Europe, Atmos. Chem. Phys., 15, 4389-4397, doi:10.5194/acp15-4389-2015, 2015.

Hartmann, S., Augustin, S., Clauss, T., Wex, H., Šantl-Temkiv, T., Voigtländer, J., Niedermeier, D., and Stratmann, F.: Immersion freezing of ice nucleation active protein complexes, Atmos. Chem. Phys., 13, 5751-5766, doi:10.5194/acp-13-57512013, 2013.

Hess, M., Koepke, P., and Schult, I.: Optical properties of aerosols and clouds: The software package OPAC, B. Am. Meteor. Soc., 79, 831-844, 1998.

Hiranuma, N., Brooks, S. D., Moffet, R. C., Glen, A., Laskin, A., Gilles, M. K., Liu, P., Macdonald, A. M., Strapp, J. W., and McFarquar, G. M.: Chemical characterization of individual particles and residuals of cloud droplets and ice crystals collected on board research aircraft in the ISDAC 2008 study, J. Geophys. Res., 118, 6564-6579, doi:10.1002/jgrd.50484, 2013.

Hiranuma, N., Augustin-Bauditz, S., Bingemer, H., Budke, C., Curtius, J., Danielczok, A., Diehl, K., Dreischmeier, K., Ebert, M., Frank, F., Hoffmann, N., Kandler, K., Kiselev, A., Koop, T., Leisner, T., Möhler, O., Nillius, B., Peckhaus, A., Rose, D., Weinbruch, S., Wex, H., Boose, Y., DeMott, P. J., Hader, J. D., Hill, T. C. J., Kanji, Z. A., Kulkarni, G., Levin, E. J. T., McCluskey, C. S., Murakami, M., Murray, B. J., Niedermeier, D., Petters, M. D., O’Sullivan, D., Saito, A., Schill, G. P., Tajiri, T., Tolbert, M. A., Welti, A., Whale, T. F., Wright, T. P., and Yamashita, K.: A comprehensive laboratory study on the immersion freezing behavior of illite NX particles: a comparison of 17 ice nucleation measurement techniques, Atmos. Chem. Phys., 15, 2489-2518, doi:10.5194/acp-15-2489-2015, 2015.

Hobbs, P. V., Politovich, M. K., and Radke, L. F.: The structure of summer convective clouds in Eastern Montana. I. Natural clouds, J. Appl. Meteorol., 19, 645-663, 1980.

Hoffmann, N., Kiselev, A., Rzesanke, D., Duft, D., and Leisner, T.: Experimental quantification of contact freezing in an electrodynamic balance, Atmos. Meas. Tech., 6, 2373-2382, doi:10.5194/amt-6-2373-2013, 2013a.

Hoffmann, N., Duft, D., Kiselev, A., and Leisner, T.: Contact freezing efficiency of mineral dust aerosols studied in an electrodynamic balance: Quantitative size and temperature dependence for illite particles, Faraday Discuss., 165, 383-390, doi:10.1039/C3FD00033H, 2013b.

Hoose, C., Lohmann, U., Erdin, R., and Tegen, I.: The global influence of dust mineralogical composition on heterogeneous ice nucleation in mixed-phase clouds, Environ. Res. Lett., 3, 025003 025017, 2008.

Joly, M., Amato, P., Deguillaume, L., Monier, M., Hoose, C., and Delort, A.-M.: Quantification of ice nuclei active at near $0{ }^{\circ} \mathrm{C}$ temperatures in low-altitude clouds at the Puy de Dôme atmospheric station, Atmos. Chem. Phys., 14, 8185-8195, doi:10.5194/acp-14-8185-2014, 2014. 
Kamphus, M., Ettner-Mahl, M., Klimach, T., Drewnick, F., Keller, L., Cziczo, D. J., Mertes, S., Borrmann, S., and Curtius, J.: Chemical composition of ambient aerosol, ice residues and cloud droplet residues in mixed-phase clouds: single particle analysis during the Cloud and Aerosol Characterization Experiment (CLACE 6), Atmos. Chem. Phys., 10, 8077-8095, doi:10.5194/acp-10-8077-2010, 2010.

Kerkweg, A., Wurzler, S., Reisin, T., and Bott, A.: On the cloud processing of aerosol particles: An entraining air parcel model with two-dimensional spectral cloud microphysics and a new formulation of the collection kernel, Q. J. Roy. Meteorol. Soc., 129, $1-18,2003$.

Khain, A., Ovtchinnikov, M., Pinsky, M., Pokrovsky, A., and Krugliak, H.: Notes on the state-of-the-art numerical modeling of cloud microphysics, Atmos. Res., 55, 159-224, 2000.

Koop, T., Beiping, L., Tsias, A., and Peter, T.: Water activity as the determinant for homogeneous ice nucleation in aqueous solutions, Nature, 406, 611-614, 2000.

Korolev, A. V., Isaac, G. A., Cober, S. G., Strapp, J. W., and Hallett, J.: Microphysical characterization of mixed-phase clouds, Q. J. Roy. Meteorol. Soc., 129, 39-65, 2003.

Krämer, M., Schiller, C., Afchine, A., Bauer, R., Gensch, I., Mangold, A., Schlicht, S., Spelten, N., Sitnikov, N., Borrmann, S., de Reus, M., and Spichtinger, P.: Ice supersaturations and cirrus cloud crystal numbers, Atmos. Chem. Phys., 9, 3505-3522, doi:10.5194/acp-9-3505-2009, 2009.

Kulkarni, G., Fan, J., Comstock, J. M., Liu, X., and Ovchinnikov, M.: Laboratory measurements and model sensitivity studies of dust deposition ice nucleation, Atmos. Chem. Phys., 12, 72957308, doi:10.5194/acp-12-7295-2012, 2012.

Ladino Moreno, L. A., Stetzer, O., and Lohmann, U.: Contact freezing: a review of experimental studies, Atmos. Chem. Phys., 13, 9745-9769, doi:10.5194/acp-13-9745-2013, 2013.

Lance, S., Shupe, M. D., Feingold, G., Brock, C. A., Cozic, J., Holloway, J. S., Moore, R. H., Nenes, A., Schwarz, J. P., Spackman, J. R., Froyd, K. D., Murphy, D. M., Brioude, J., Cooper, O. R., Stohl, A., and Burkhart, J. F.: Cloud condensation nuclei as a modulator of ice processes in Arctic mixed-phase clouds, Atmos. Chem. Phys., 11, 8003-8015, doi:10.5194/acp-11-80032011, 2011.

Lee, S. S., Donner, L. J., and Phillips, V. T. J.: Impacts of aerosol chemical composition on microphysics and precipitation in deep convection, Atmos. Res., 94, 220-237, 2009.

Leroy, D., Monier, M., Wobrock, W., and Flossmann, A. I.: A numerical study of the effects of the aerosol particle spectrum on the development of the ice phase and precipitation formation. Atmos. Res., 80, 15-45, doi:10.1016/j.atmosres.2005.06.007, 2006.

Levin, Z. and Yankofsky, S. A.: Contact versus immersion freezing of freely suspended droplets by bacterial ice nuclei, J. Clim. Appl. Meteorol., 22, 1964-1966, 1983.

Lohmann, U. and Diehl, K.: Sensitivity studies of the importance of dust nuclei for the indirect aerosol effect on stratiform mixedphase clouds, J. Atmos. Sci., 63, 968-982, 2006.

Manninen, H .E., Bäck, J., Sihto-Nissilä, S.-L., Huffman, J. A., Pessi, A.-M., Hiltunen, V., Aalto, P. P., Hidalgo, P .J., Hari, P., Saarto, A., Kulmala, M., and Petäjä, T.: Patterns in airborne pollen and other primary biological aerosol particles (PBAP), and their contribution to aerosol mass and number in a boreal forest, Boreal Environ. Res., 19 (suppl. B), 383-405, 2014.

Matthias-Maser, S. and Jaenicke, R.: Size distribution of primary biological aerosol particles with radii $\geq 0.2 \mu \mathrm{m}$, J. Atmos. Res., 39, 279-286, 1995.

McFarquhar, G., Zhang, G., Poellot, M. R., Kok, G. L., MaCoy, R., Tooman, T., Fridlind, A., and Heymsfield, A. J.: Ice properties of single-layer stratocumulus during the Mixed-Phase Arctic Cloud Experiment: 2. Observations. J. Geophys. Res., 112, D24201, doi:10.1029/2007JD008633, 2007.

Möhler, O., Field, P. R., Connolly, P., Benz, S., Saathoff, H., Schnaiter, M., Wagner, R., Cotton, R., Krämer, M., Mangold, A., and Heymsfield, A. J.: Efficiency of the deposition mode ice nucleation on mineral dust particles, Atmos. Chem. Phys., 6, 3007 3021, doi:10.5194/acp-6-3007-2006, 2006.

Murray, B. J., Broadley, S. L., Wilson, T. W., Atkinson, J. D., and Wills, R. H.: Heterogeneous freezing of water droplets containing kaolinite particles, Atmos. Chem. Phys., 11, 4191-4207, doi:10.5194/acp-11-4191-2011, 2011.

Paukert, M. and Hoose, C.: Modeling immersion freezing with aerosol-dependent prognostic ice nuclei in Arctic mixedphase clouds. J. Geophys. Res. Atmos., 119, 9073-9092, doi:10.1002/2014JD021917, 2014.

Phillips, V. T. J., Donner, L. J., and Garner, S. T.: Nucleation processes in deep convection simulated by a cloud-system-resolving model with double-moment bulk microphysics, J. Atmos. Sci., 64, 738-761, 2007.

Phillips, V. T. J., DeMott, P. J., and Andronache, C.: An empirical parameterization of heterogeneous ice nucleation for multiple chemical species of aerosol, J. Atmos. Sci., 65, 2757-2783, 2008.

Phillips, V. T. J., Andronache, C., Christner, B., Morris, C. E., Sands, D. C., Bansemer, A., Lauer, A., McNaughton, C., and Seman, C.: Potential impacts from biological aerosols on ensembles of continental clouds simulated numerically, Biogeosciences, 6 , 987-1014, doi:10.5194/bg-6-987-2009, 2009.

Pitter, R. L. and Pruppacher, H. R.: A wind tunnel investigation of freezing of small water drops falling at terminal velocity in air, Q. J. Roy. Meteorol. Soc., 99, 540-550, 1973.

Pruppacher, H. R. and Klett, J. D.: Microphysics of Clouds and Precipitation, 2nd rev. exp. Edn., Atmospheric and Oceanographic Sciences Library, 18, Springer Science \& Business Media, 2010.

Reid, J. S., Hobbs, P. V., Ferek, R. J., Blake, D. R., Martins, J. V., Dunlap, M. R., and Liousse, C.: Physical, chemical, and optical properties of regional hazes dominated by smoke in Brazilm J. Geophys. Res., 103, 32059-32080, 1998.

Sattler, B., Puxbaum, H., and Psenner, R.: Bacterial growth in supercooled cloud droplets, Geophys. Res. Lett., 28, 239-242, 2001.

Schmidt, S., Schneider, J., Klimach, T., Mertes, S., Schenk, L. P., Curtius, J., Kupiszewski, P., Hammer, E., Vochezer, P., Lloyd, G., Ebert, M., Kandler, K., Weinbruch, S., and Borrmann, S.: In-situ single submicron particle composition analysis of ice residuals from mountain-top mixed-phase clouds in Central Europe, Atmos. Chem. Phys. Discuss., 15, 4677-4724, doi:10.5194/acpd15-4677-2015, 2015.

Simmel, M. and Wurzler, S.: Condensation and nucleation in sectional cloud microphysical models based on the linear discrete method, Atmos. Res., 80, 218-236, 2006. 
Simmel, M., Trautmann, T., and Tetzlaff, G.: Numerical solution of the stochastic collection equation - Comparison of the linear discrete method with other methods, Atmos. Res., 61, 135-148, 2002.

Simmel, M., Diehl, K., and Wurzler, S.: Numerical simulation of the microphysics of an orographic cloud: Comparison with measurements and sensitivity studies, Atmos. Environ., 39, 4365-4373, 2005.

Storelvmo, T., Kristjánsson, J. E., and Lohmann, U.: Aerosol influence on mixed-phase clouds in CAM-Oslo, J. Atmos. Sci., 65, 3214-3230, 2008.

Straka, H.: Pollen- und Sporenkunde, Fischer Verlag, Stuttgart, 1975.

Twohy, C. H. and Anderson, J. R.: Droplet nuclei in nonprecipitating clouds: composition and size matter, Environ. Res. Lett., 3, 045002, doi:10.1088/1748-9326/3/4/045002, 2008.

Vali, G.: Quantitative evaluation of experimental results on the heterogeneous freezing nucleation of supercooled liquids, J. Atmos. Sci., 28, 402-409, 1971.

van den Heever, S. C., Carrió, G. G., Cotton, W. R., DeMott, P. J., and Prenni, A. J.: Impacts of Nucleating Aerosol on Florida Storms. Part I: Mesoscale Simulations, J. Atmos. Sci., 63, 17521775, 2006.

v. Blohn, N., Mitra, S. K., Diehl, K., and Borrmann, S.: The ice nucleating ability of pollen. Part III: New laboratory studies in immersion and contact freezing modes including more pollen types, Atmos. Res., 78, 182-189, 2005.
Weber, D.: Eisnukleation von Aerosolen: Laborexperimente und Messung von Schiffsemissionen, MSc-thesis, Goethe University, Frankfurt/M., 2014.

Wex, H., Augustin-Bauditz, S., Boose, Y., Budke, C., Curtius, J., Diehl, K., Dreyer, A., Frank, F., Hartmann, S., Hiranuma, N., Jantsch, E., Kanji, Z. A., Kiselev, A., Koop, T., Möhler, O., Niedermeier, D., Nillius, B., Rösch, M., Rose, D., Schmidt, C., Steinke, I., and Stratmann, F.: Intercomparing different devices for the investigation of ice nucleating particles using Snomax ${ }^{\circledR}$ as test substance, Atmos. Chem. Phys., 15, 14631485, doi:10.5194/acp-15-1463-2015, 2015.

Worringen, A., Kandler, K., Benker, N., Dirsch, T., Mertes, S., Schenk, L., Kästner, U., Frank, F., Nillius, B., Bundke, U., Rose, D., Curtius, J., Kupiszewski, P., Weingartner, E., Vochezer, P., Schneider, J., Schmidt, S., Weinbruch, S., and Ebert, M.: Singleparticle characterization of ice-nucleating particles and ice particle residuals sampled by three different techniques, Atmos. Chem. Phys., 15, 4161-4178, doi:10.5194/acp-15-4161-2015, 2015.

Yakobi-Hancock, J. D., Ladino, L. A., and Abbatt, J. P. D.: Feldspar minerals as efficient deposition ice nuclei, Atmos. Chem. Phys., 13, 11175-11185, doi:10.5194/acp-13-11175-2013, 2013.

Zimmermann, F., Weinbruch, S., Schütz, L., Hofmann, H., Ebert, M., Kandler, K., and Worringen, A.: Ice nucleating properties of the most abundant mineral dust phases, J. Geophys. Res., 113, D23204, doi:10.1029/2008JD010655, 2008. 